2016

\title{
Reaping the Whirlwind: The Caddo after Europeans
}

Timothy K. Perttula

Heritage Research Center, Stephen F. Austin State University

Robert Cast

Follow this and additional works at: https://scholarworks.sfasu.edu/ita

Part of the American Material Culture Commons, Archaeological Anthropology Commons, Environmental Studies Commons, Other American Studies Commons, Other Arts and Humanities Commons, Other History of Art, Architecture, and Archaeology Commons, and the United States History Commons

Tell us how this article helped you.

This Article is brought to you for free and open access by the Center for Regional Heritage Research at SFA ScholarWorks. It has been accepted for inclusion in Index of Texas Archaeology: Open Access Gray Literature from the Lone Star State by an authorized editor of SFA ScholarWorks. For more information, please contact cdsscholarworks@sfasu.edu. 


\section{Reaping the Whirlwind: The Caddo after Europeans}

Creative Commons License

(c) (i) (8)

This work is licensed under a Creative Commons Attribution-NonCommercial 4.0 International License 


\title{
Reaping the Whirlwind: The Caddo after Europeans
}

\author{
Timothy K. Perttula and Robert Cast
}

\section{INTRODUCTION}

The De Soto chronicles introduce us to the Caddo Indian peoples of East Texas in what we can arbitrarily call "historic times." The Gentleman of Elvas had this to say when the Spaniards reached the Caddo province of Naguatex on the Red River in the Great Bend area of southwestern Arkansas in August of 1542:

The cacique [of Naguatex], on beholding the damage that his land was receiving [from the Spanish forces], sent six of his principal men and three Indians with them as guides who knew the language of the region ahead where the governor [Luis de Moscoso] was about to go. He immediately left Naguatex and after marching three days reached a town of four or five houses, belonging to the cacique of that miserable province, called Nisohone. It was a poorly populated region and had little maize. Two days later, the guides who were guiding the governor, if they had to go toward the west, guided then toward the east, and sometimes they went through dense forests, wandering off the road. The governor ordered them hanged from a tree, and an Indian women, who had been captured at Nisohone, guided them, and he went back to look for the road (Robertson 1933:145) [brackets added].

Despite the "miserable" condition of the lands traversed by the Spaniards in Caddo country, the Caddo were successful agriculturists, with a Mississippian societal flavor, as well as bison hunters when they were first described in 1542 by the Spanish expedition.

In the last few years, Caddo archaeologists and ethnohistorians have devoted attention to the study of contact between Europeans and Caddo peoples, particularly to considerations of the effects of that contact on the nature of changes in Caddo societies. Much of this recent consideration seems to have been occasioned by a new-found ethnohistoric interest by Caddo researchers in: (a) determining the routes of Spanish and French explorers and colonists, particularly Hernando de Soto and La Salle, and (b) reconstructing the socio-political character and ethnic identity of prehistoric and early historic Native American groups. Much ink has been spilled concerning the route of the de Soto entrada in Caddo country, and of the locations of the Caddo groups who were contacted by the Spanish in 1542-1543. It is debatable, however, whether this intense scrutiny of the route, or of the groups contacted, has produced significant insights into what the effects of that contact on Caddo communities might have been.

What were the population and disease effects on native Caddo groups of European contact initiated by the de Soto entrada? Archaeological, bioarcheological, and historical data have been closely scrutinized, but there is no consensus on such issues as: (1) Caddo population histories across space and through time, (2) when epidemic diseases were introduced into the Caddo area, (3) when post-contact population declines occurred, and (4) what the long-term cultural impacts of those declines where on Caddo societies and communities.

Fairly robust post-1540 Caddo bioarchaeological assemblages have been studied from a few sites across the Caddo area. However, archaeological sites dating to this period are not yet consistently examined with an eye to characterizing aspects of Caddo cultural change related to demographic or health conditions (i.e., abandonment of regions and major sites or discontinuation of mound building, for example); instead, the main issues have remained those of chronology and function, and of late the question of ethnic and cultural affiliation has become important. 
The Caddo peoples in historic times comprised at least 25 distinct but closely affiliated groups centering geographically around the Great Bend of the Red River and extending into the Pineywoods of deep East Texas. Eventually, because of population loss, tribal movements, and village abandonments, these Caddo affiliated groups became organized into the Hasinai, Kadohadacho, and Natchitoches confederacies - best understood as kin-based affiliated groups of Caddo communities. This group consolidation and coalescence occurred in the Neches and Angelina river valleys in East Texas, the Great Bend area of the Red River, and in the vicinity of the French post of Natchitoches (Louisiana), respectively. The Hasinai Caddo groups continued to live through the 1830s in their traditional East Texas homelands, while the Natchitoches did the same in western Louisiana, but the Kadohadacho were forced to move off the Red River in the late 1780s to the Caddo Lake area, along the boundary between the territory of Louisiana and the province of Texas. Some Kadohadacho remained there until the late 1830s at the village of Sha'chahdinnih or Timber Hill (41MR211) as well as several other sites south of Caddo Lake, in modern Harrison County, Texas. Other groups such as the Nadaco (in the Sabine and Neches River basins) and Nabedache (in the Neches River basin) maintained more independent communities through much of the contact era, although both Caddo groups were eventually considered part of the Hasinai confederacy.

The Caddo peoples trace descent through the maternal line, with matrilineality reflected in kinship terms. They also recognized and ranked clans, with marriage typically occurring between members of different clans. Religious and political authority in historic Caddo communities rested in a hierarchy of key positions shared between the various affiliated communities and groups. The xinesi (pronounced chenesi, meaning Mr. Moon) inherited the position of spiritual leadership, the caddi the position of principal headman of a community, which was also inherited from father to son, and the canahas, the position of village elder or subordinate headman. The Caddo people looked to the xinesi for mediation and communication with their supreme god, the Caddi Ayo, for religious leadership and decision-making influence, and in leading certain special rites, including the first-fruits, harvest, and naming ceremonies. In essence, the xinesi imbued everyday life for the Caddo peoples with the supernatural. The caddi was primarily responsible for making the important political decisions for the community, sponsoring other major ceremonies of a diplomatic nature, leading councils for war/raiding expeditions, and conducting the calumet (or peace pipe) ceremony with important visitors to the communities.

Considerable research attention has been devoted of late to Caddo area archaeology and Native history, particularly concerning the Caddo communities, hamlets, and farmsteads that existed about the time of the European settlement of the "Great Kingdom of the Tejas." The "Great Kingdom of the Tejas," known to be a populous and well-governed people, was how the Caddo peoples of East Texas were first described by the Spanish in the mid-1600s from the accounts of Jumano Indian traders.

Into the world of the Caddo peoples entered the Spanish entrada of Hernando de Soto, now led by Luis de Moscoso, who passed through Caddo lands in present-day Arkansas, Texas, and Louisiana in 1542-1543. Perhaps not far behind were the epidemic diseases introduced by the Europeans. When the Europeans of La Salle's expedition next arrived among the Caddo (in this case the Hasinai tribes) in 1686, the Caddo peoples lived primarily in small groups on the Red River and in various locales in East Texas. Through their missions, ranches, trading posts, and fur traders, the far edges of the French and Spanish empires laid claim to the land and loyalties of the Caddo Indians. Epidemics greatly reduced Caddo populations - possibly by as much as 95 percent between 1691 and 1816. The Caddo were well situated to participate in the French fur trade, however, and they traded guns, horses, and other essential items to Indian groups and Europeans, and in the process they developed new trade and economic networks, as well as acquired new European goods and ornaments. The resulting economic symbiosis between the Caddo groups and Europeans was the key to the political success and strength of the Caddo tribes through much of the colonial era. 


\section{Late $17^{\text {th }}$ to Early $18^{\text {th }}$ Century Archaeological Context}

\section{Hatchel site}

The Hatchel site (41BW3) was a large Nasoni Caddo village on the Red River, not far from the modern city of Texarkana. The site contained at least five earthen mounds, including one primary platform mound, with many levels of important public or elite-occupied buildings, that stood $30 \mathrm{ft}$. high. It had extensive domestic habitation and cemetery areas covering several hundred acres around the mounds and adjacent to an old channel of the Red River. When the village was first visited in 1687 by Henri Joutel, Henri de Tonti in 1690, and Don Domingo Teran de los Rios in 1691, it stretched for several miles along the river.

The village would have been impressive to behold. Freeman and Custis described the principal Caddo village on the Red River, abandoned in 1788, as follows:

Around and near to this pond [on the Red River], are to be seen the vestiges of the Caddo habitations; it was the largest of their villages, and their cultivated fields extended for five or six miles from it in every direction (Flores 1984:188).

The site was first occupied as early as ca. A.D. 1100-1200, and that occupation lasted to the late 1780s. It was the premier Caddo civic and ceremonial center for a considerable part of the Red River valley. During excavations in the 1930s and 2003, several village areas with structures, post holes, midden deposits, and burials were identified east, southeast, and southwest of the primary mound. A plaza was present south of the primary mound when it was visited by Teran de los Rios. The primary mound itself was composed of several stages of mound construction fill, with most of the mound fill stages built to cover large (9-10 $\mathrm{m}$ in diameter) circular house structures that stood on the mound (Figure 1). Many had extended entranceways, typically indicating an important Caddo public structure or one lived in by members of the social elite. The initial mound stage was built over an even larger circular structure (ca. $13 \mathrm{~m}$ in diameter) that stood on the original ground surface and may have been built some time between ca. A.D. 1100-1300. The remainder of the primary mound, and much of the village, was used by the Caddo between A.D. 1300-1700.

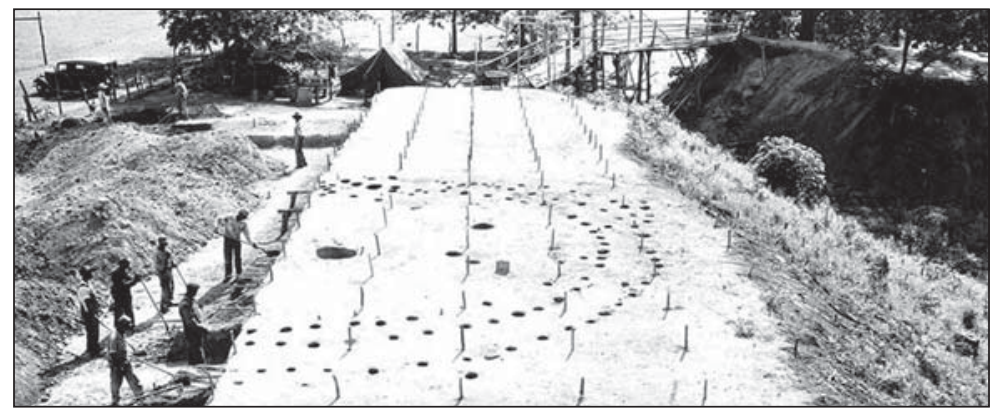

Figure 1. Post hole outlines on the primary mound at the Hatchel site.

When the Teran entrada reached the Nasoni Caddo village in 1691, his mapmaker had produced a detailed map of the village. It depicted a templo or temple mound at the western end of the village; this is believed to be the primary platform mound at the Hatchel site. The caddi or political leader lived a few miles away at either the Eli Moores (41BW2) or Horace Cabe (41BW14) mound sites. As documented on this map, individual farm compounds in the village contained one to three structures, an above-ground granary, and an outdoor ramada or arbor (Figure 2). At least 36 structures, including family and chiefly residences, were arranged within the numerous compounds. The residence of the caddi near the center of the village was marked by a large cross, possibly erected by Father Damian Massanet, who accompanied the expedition. 


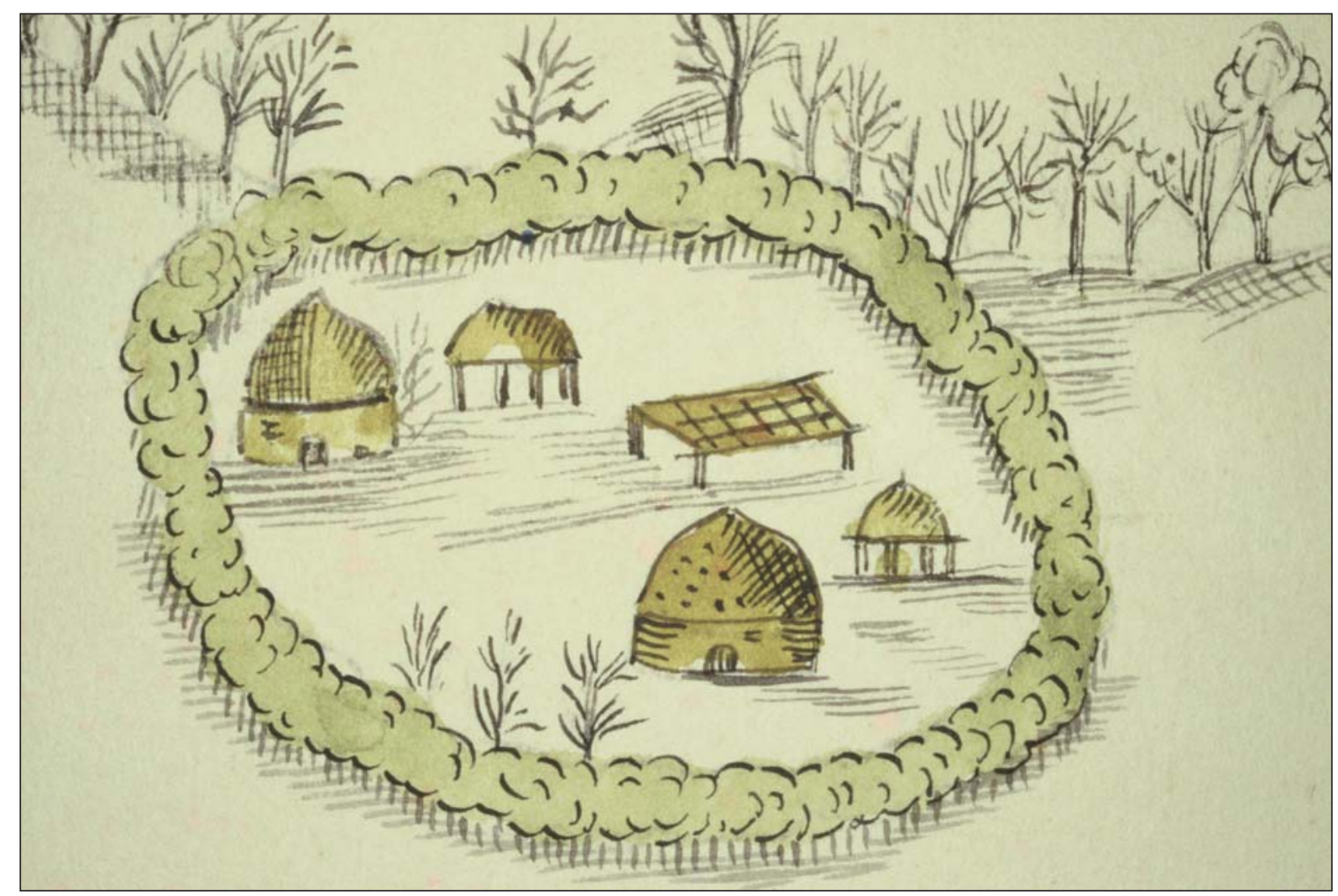

Figure 2. Detail of a farmstead compound on the 1691 Teran map.

\section{Clements site}

The Clements site $(41 \mathrm{CS} 25)$ is a late $17^{\text {th }}$ to early $18^{\text {th }}$ century Nasoni Caddo settlement and cemetery in the Black Bayou basin in the northeastern Texas Pineywoods, not far from the Caddo Trace. The Caddo Trace was an aboriginal trail that led from the Hasinai Caddo settlements in East Texas to the Kadohadacho settlements on the Red River in the general area of Texarkana, Texas, and its route is fairly well-known because the historic $19^{\text {th }}$ century Trammel's Trace followed its route through northeastern Texas.

The site was first explored in 1898 by a W. T. Scott, then by the University of Texas in 1932, and this work led to the excavation of 22 Nasoni Caddo graves as well as a small midden or trash deposit. An undiscovered collection of artifacts from a number of graves at Clements were studied in the last few years by the Caddo Nation of Oklahoma as part of Native American Graves Protection and Repatriation Act consultation between the Nation and the American Museum of Natural History.

As best we can tell from the distribution of the different kinds of funerary objects in the 22 burials, the Clements site was used as a place for the Caddo to bury their dead during at least two different periods or episodes that may have lasted a generation or more. The earlier cemetery use includes burials in several north-south rows at the western end of the site, including burials 8-13,16-20, and 21 (Figure 3). Sometime around the beginning of the $18^{\text {th }}$ century, the eastern half of the cemetery was used (Burials $1-7,14$, and 15); these burials had among their various offerings a few strands of European glass beads traded to the Nasoni Caddo by Europeans. One of the western burials (Burial 21) also was part of this later cemetery, as this individual had a Keno Trailed, var. Phillips bowl among its funerary offerings, and this ceramic form is thought to be an excellent ceramic marker for the period between ca. 1700-1730.

A relatively diverse assemblage of funerary objects was recovered from the site. Conch shell ornaments made from Gulf Coast marine shells were the most common item placed with the deceased, including probable 


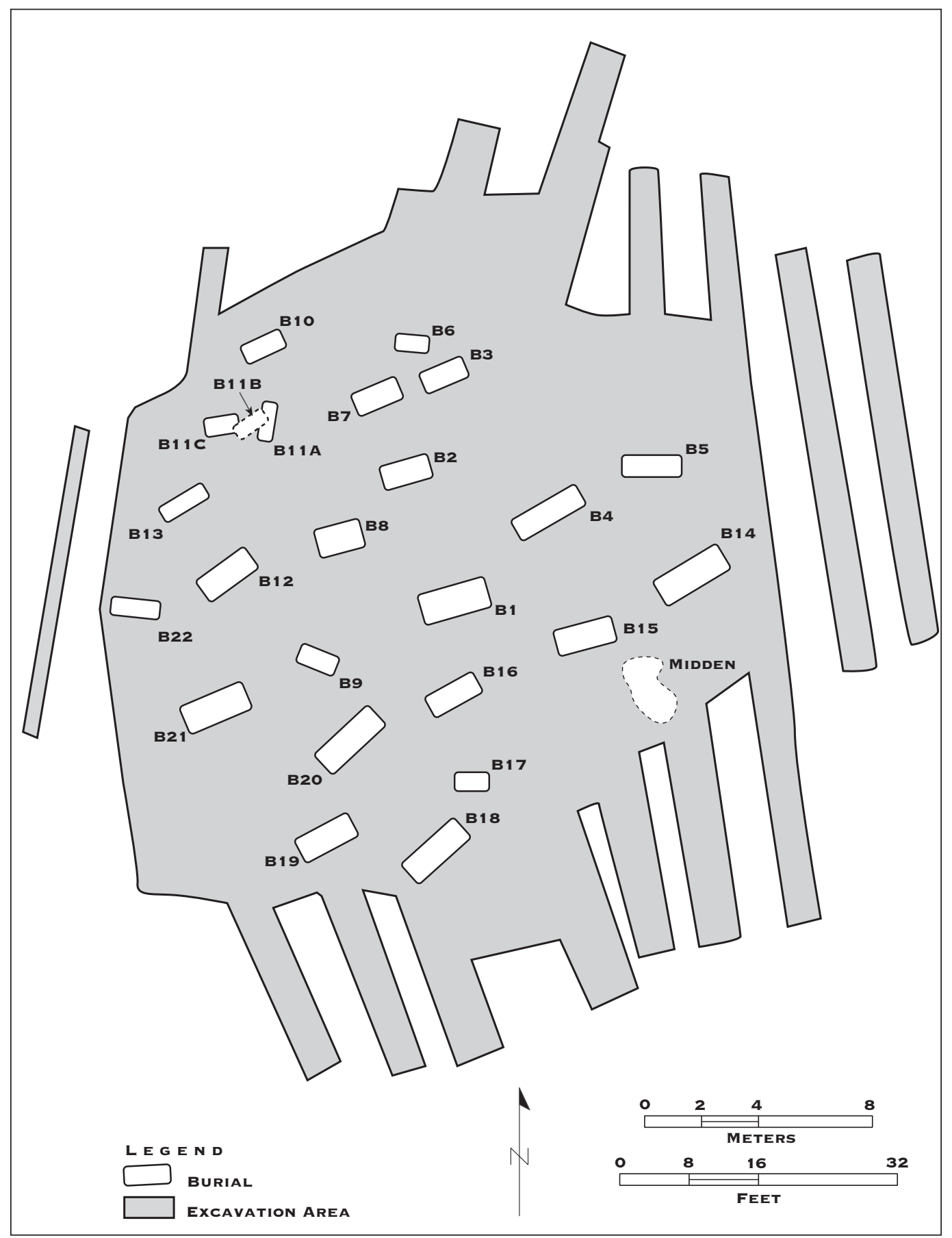

Figure 3. Map of the arrangement of the Clements site burials.

bead necklaces in at least three burials (Burials 2, 8, and 15), bracelets (Burial 15), ear discs, and portions of pendant necklaces (Figure 4). The zoomorphic style of the conch shell pendants from the associated midden at the Clements site is very similar to ones recovered at both the Belcher and Cedar Grove sites on the Red River in northwestern Louisiana and southwestern Arkansas, as well as from Belcher phase components (ca. A.D. 1500-1700) at the Foster, Friday, and Battle sites along the Red River in southwestern Arkansas.

Half of the Clements burials had conch shell ornaments, which certainly seems indicative of a ready access to these materials of exotic origin (i.e., the conch shell would have been found along the Gulf Coast of 

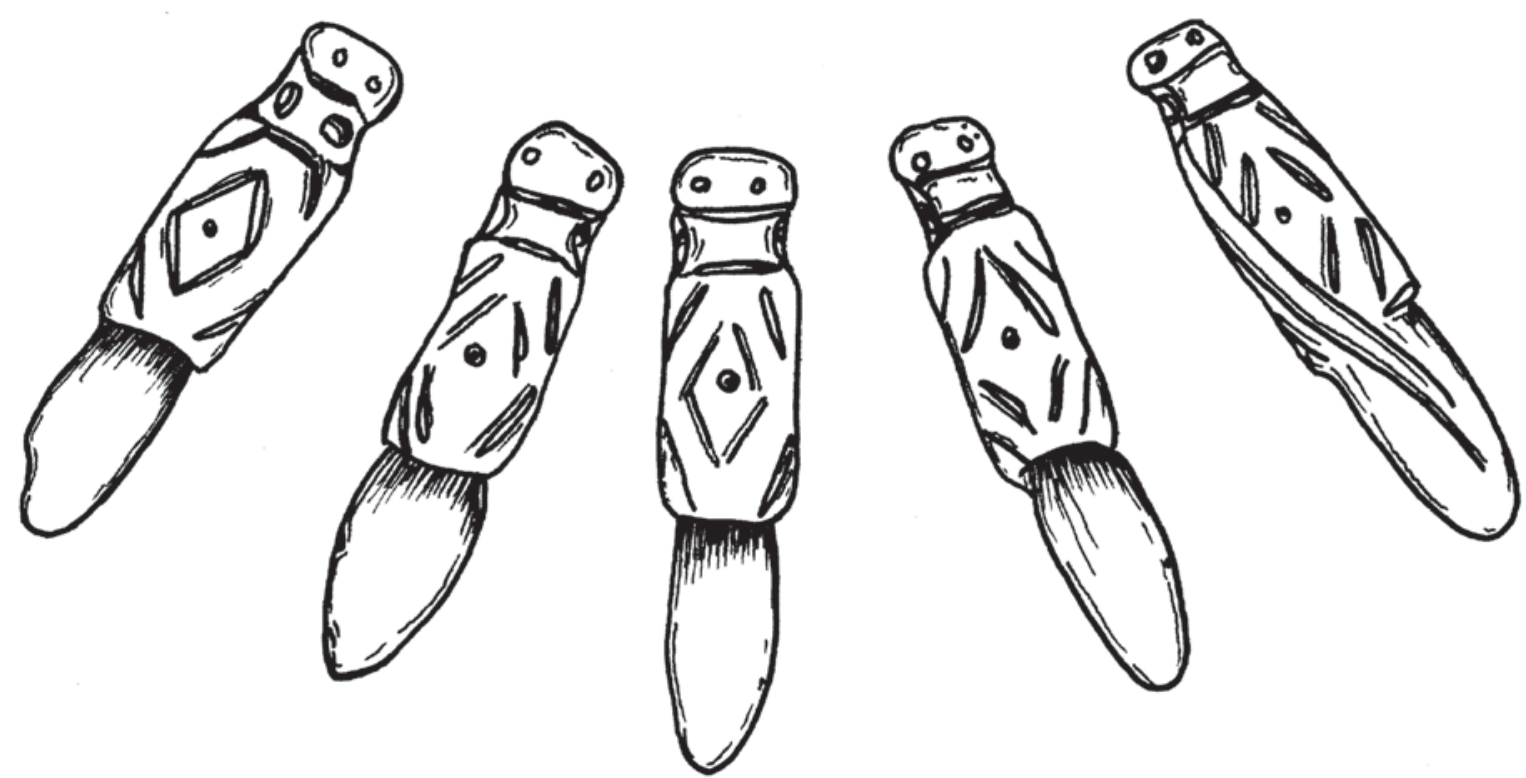

Figure 4. Marine shell pendants. Drawings by Bobby Gonzalez.

Texas); a similar relationship was noted in the post-A.D. 1680 Chakanina phase burials at the Cedar Grove site. Along with the shell ornaments were European glass beads (1-26 beads per burial) from five separate interments at Clements. In two instances, shell beads or other shell ornaments were found together in the same burial with the European glass beads.

Pottery vessels were also commonly placed as funerary offerings in the burials, with as many as nine vessels placed with Burial 11. Others had between 1-6 vessels per burial. Fifteen of the burials at the Clements site had clay pigment (green, brown, red, and gray colors) and/or mussel shell offerings. Four of the five burials with European trade goods had pigments, particularly a green pigment from a local glauconitic clay.

\section{Gilbert site}

The Gilbert site (41RA13) is a mid-18 $8^{\text {th }}$ century site on a large alluvial terrace of Lake Fork Creek, near its headwaters, in the far western reaches of the Post Oak Savannah in East Texas. The site is marked by 20 small midden mounds that appear to represent trash heaps spread out across about 14 acres of the landform (Figure 5); there were trash-filled storage pits in a few of the midden mounds. The site was excavated by the Texas Archeological Society (TAS) in 1962, and there have been subsequent intensive metal detecting work done by Jay C. Blaine, a noted expert on European metal trade goods.

Based on the kinds and range of both aboriginal and European artifacts recovered at the Gilbert site in the TAS excavations and later work, the site most likely is a seasonally-occupied hunting camp settled by a horsebound Caddo group engaged in the burgeoning French-Caddo fur trade. Distinctive Historic Caddo pottery (from at least 47 vessels), including sherds from Womack Engraved vessels (Figure 6), Simms Engraved, Natchitoches Engraved, Emory Punctated-Incised, and Womack Plain types, is relatively abundant in the middens. So too are chipped stone tools, among them about 200 triangular-shaped arrow points (as well as about 20 metal arrow points fashioned by the Caddo from recycled European iron and brass), more than 500 side and end scrapers (Figure 7), and more than 50 knives, drills, and graving tools. The frequency of scrapers is indicative of the intensive processing of white-tailed deer for their hides and meat. 


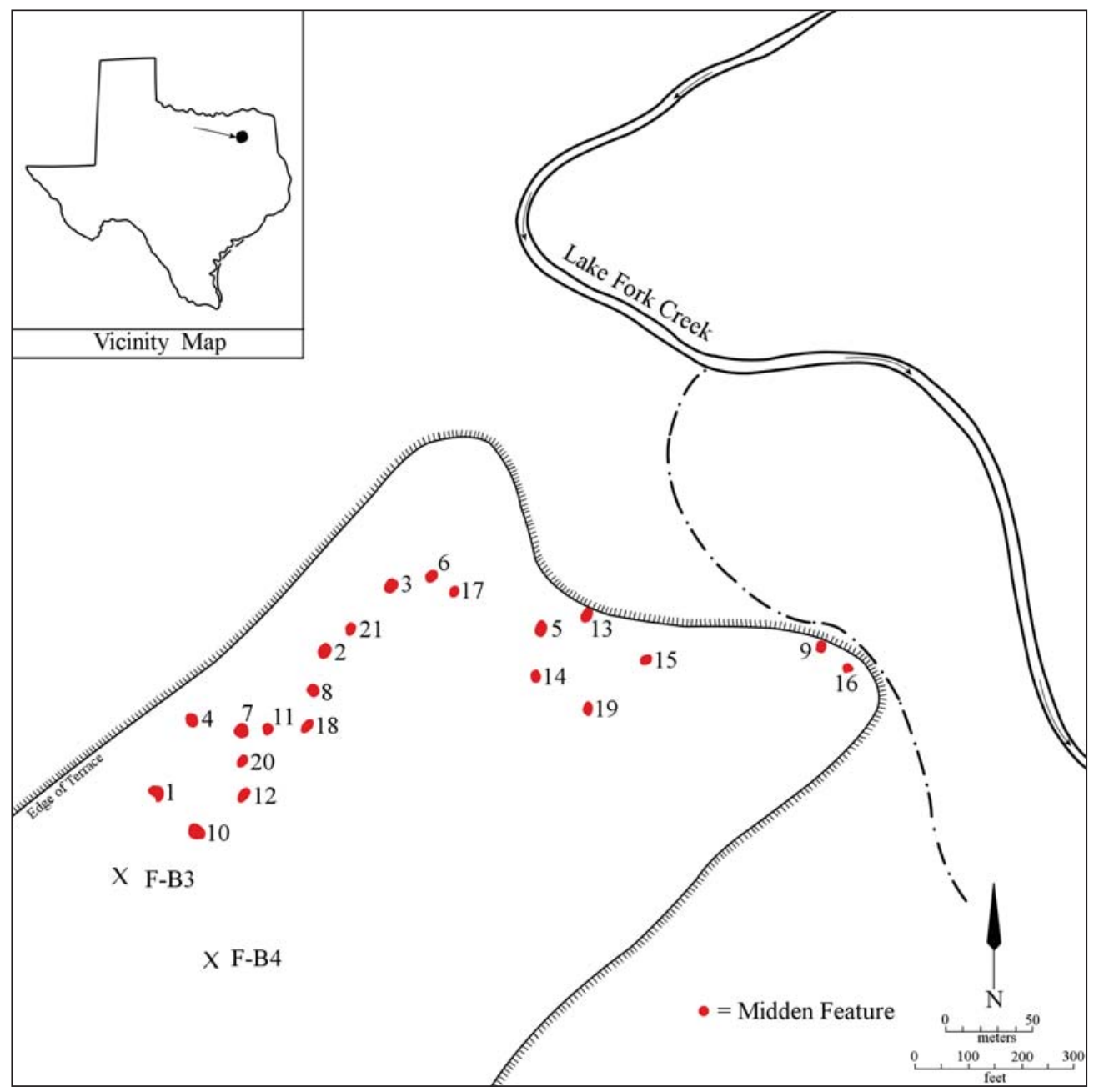

Figure 5. Map of the middens at the Gilbert site.

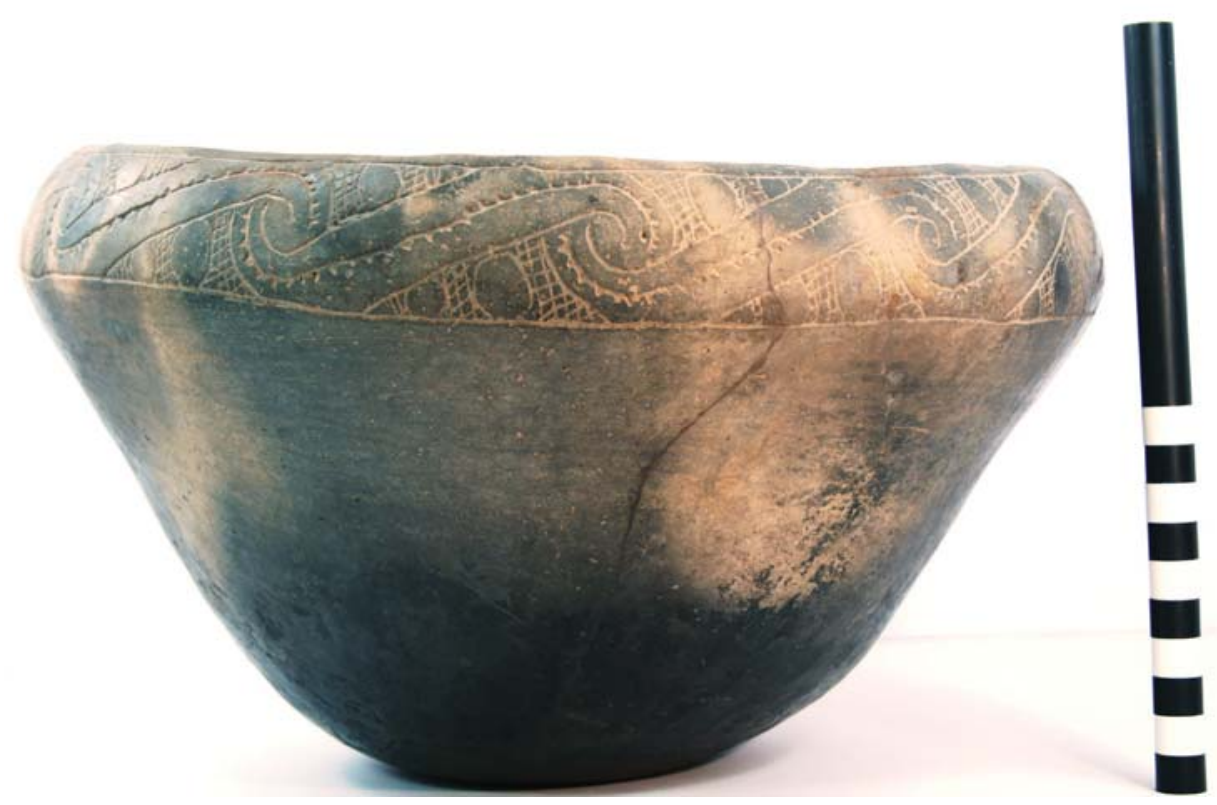

Figure 6. Womack Engraved vessel section from the Womack site. 


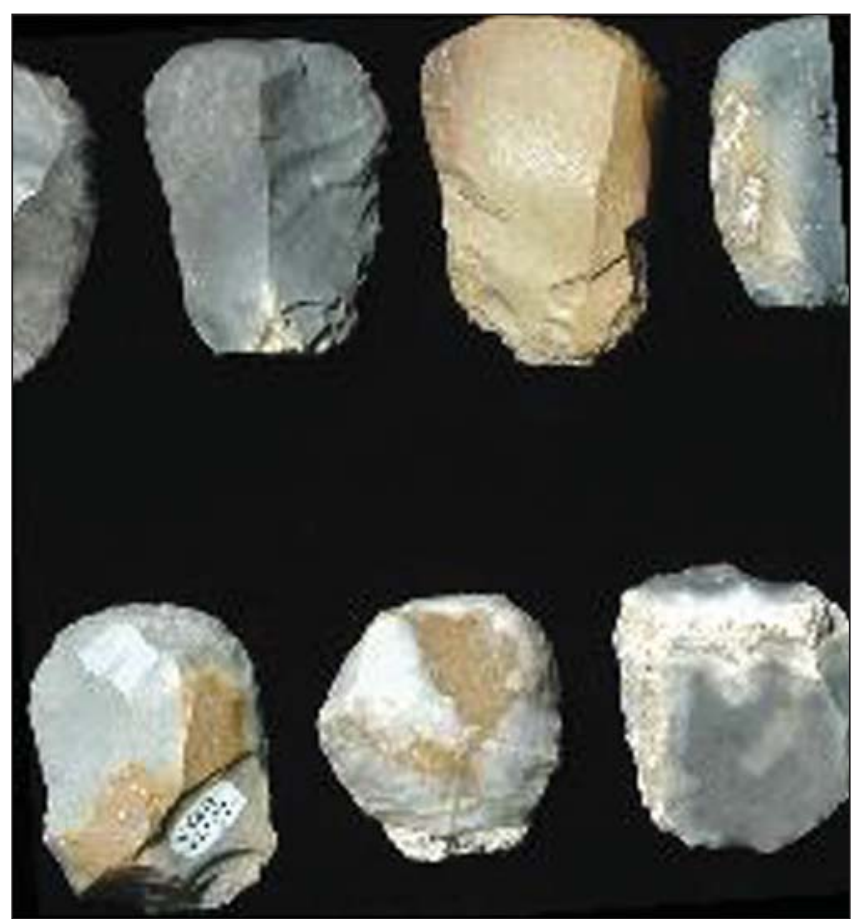

Figure 7. Chipped stone scrapers from the Gilbert site. Reproduced courtesy of Texas Beyond History, The University of Texas at Austin.

Certainly the most distinct aspect of the Gilbert site artifact assemblage is the quantity and diversity of European trade goods found in the midden mounds. Pieces from French flintlock trade guns are particularly common, including elaborately decorated butt plates (Figure 8), as well as lock plates, frizzens, iron gun cocks, gunlocks, ramrod guides, trigger guards, and gun barrel fragments. Both aboriginal and French-made gunflints are present, and about 60 percent of the gunflints were probably made by Caddo stone tool knappers.

These Caddo hunters also had ready access to many other kinds of European trade goods beyond the flintlock guns; they were likely obtained from French traders for deer hides, bear grease, and other products of the hunt. It has been estimated that at least 20 French "firearms were discarded and reduced to parts and fragments here." There are metal French clasp and case knives, axes, wedges, hoes, hatchets, awls, and scissors, possible Spanish sword fragments, and possible ornaments attached to clothing or worn on the body, such as hawk bells, tinklers, pendants, finger rings, bracelets, and $3400+$ glass beads. There were also pieces of brass kettles, horse trappings and gear (bridles), glass mirrors, and bottle glass.

\section{Deshazo site}

Excavations at the Deshazo site (41NA13), a well-studied Historic Caddo Allen phase settlement situated just north of El Camino Real de los Tejas, on an alluvial fan near Bayou Loco in deep East Texas, indicates it was a small centralized hamlet of an affiliated group with a series of nine circular structures and an associated household or family cemetery. The site was apparently occupied for only a short period of time between the late $17^{\text {th }}$ and early $18^{\text {th }}$ century, perhaps 20 to 40 years, based on an analysis of structure rebuilding episodes and the size of the family cemetery.

The structures occurred in three different clusters, with evidence of structure rebuilding in northern (Structures 4-6) and southern clusters (Structures 1-3, 7, and 9), with an open courtyard or small plaza between them; Structure 8 was on the opposite side of the creek from the main settlement area. A communal 


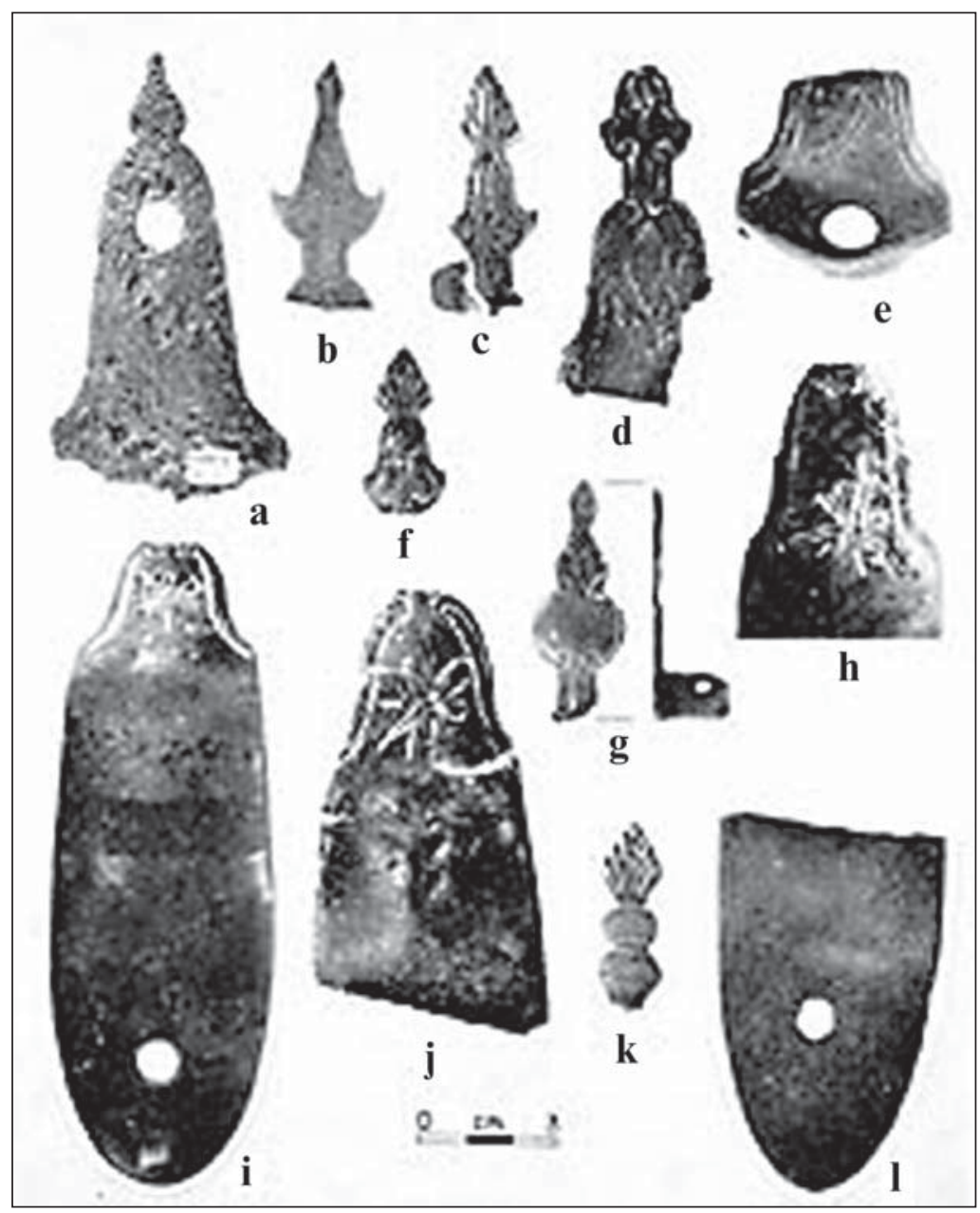

Figure 8. Brass butt plates from the Gilbert site. Reproduced courtesy of Texas Beyond History, The University of Texas at Austin.

trash midden accumulated immediately to the south of the southern cluster of house structures. The structures ranged between 9-12.2 $\mathrm{m}$ in diameter, had single center posts, and there were large clay-lined hearths inside as well as immediately outside several of the structures. Three children were buried in pits dug through the floor of two of the structures (Structures 3 and 9) in the village. Each of these burials had a single ceramic vessel left as a funerary offering.

The site contain small amounts of European trade goods found to only a limited extent in the village but more commonly in burial contexts. The family cemetery had 10 adult individuals that were buried in an extended supine position with the deceased's heads facing uniformly towards the northwest. The majority of the European goods used as funerary objects were glass beads $(n=4600+)$ worn as necklaces that accompanied the deceased on their journey to what the Caddo peoples considered the House of the Dead in the sky. Other funerary offerings included 13 ceramic vessels, several stone tools, a clay pipe, pigments, metal trade goods (iron knives and a bell), and a possible rattle.

Caddo domestic remains at this settlement included an abundance of a variety of plain and decorated ceramic fine wares (principally Patton Engraved) and utility wares, the latter usually bone-tempered and with brushed vessel bodies, triangular and stemmed arrow points (including Turney and Perdiz types), elbow pipes (plain and decorated), ground stone tools, and bone tools. The Caddo group that lived at the Deshazo site were successful agriculturists. 


\section{J. T. King site}

The J. T. King site (41NA15) is an early $18^{\text {th }}$ century Caddo or Hasinai Caddo habitation site in East Texas. It is located directly on the northern route of El Camino Real de los Tejas National Historic Trail in western Nacogdoches County, Texas. It is on an alluvial terrace along the west side of King Creek, and about $5 \mathrm{~km}$ east of the Camino Real's northern crossing of the Angelina River.

Archaeogeophysical work (covering 2.5 hectares) was done at the site in 2008 and 2010 using a Bartington Fluxgate gradiometer mounted on a two-wheeled cart. That research obtained significant data on the spatial organization of a Caddo settlement that was occupied at the time of the Spanish colonization of East Texas, particularly information on the layout of buildings, courtyards, granaries, and other domestic features, as well as their spatial interrelationships.

The interpretation of the magnetometer data is that there are 10 possible Caddo structures in the archaeogeophysical survey area, and they are round to sub-round in shape and range from 3.7-12.5 m in diameter. Seven of the possible structures have anomalies situated in or close to their center that may be central hearths or large center posts inside the domestic structures. None of the possible structures have complete geophysical signatures and it is not possible to make out an entranceway or easily discern the orientation of the structures. An area with a drop in background magnetic activity in the central part of the eastern collection area is a possible courtyard that is flanked by structures of different shapes and sizes (Figure 9).

Excavations at the J. T. King site have documented that it is a substantial Historic Caddo habitation site, with well-preserved archaeological deposits and domestic features. The overall character of the collected material culture assemblage from the site correlates well with other Allen phase sites in western Nacogdoches County along Bayou Loco, Legg Creek, and the Angelina River.

These excavations at the site recovered thousands of ceramic sherds, including sherds from bowls and carinated bowls from the principal fine ware type, Patton Engraved (Figure 10), ceramic elbow pipe sherds, pieces of burned clay, lithic debris and chipped stone flake tools and arrow points, chipped stone Jowell knives, copper or brass tinkler cone fragments made from kettle fragments, glass beads, and lead balls for use in a flintlock musket, and animal bone, as well as charred plant remains. The plant remains recovered from the J. T. King site reflect the Caddo exploitation of the local forests for fuel wood and nut resources, the cultivation of corn, and the collection of cane or other grass stems for construction or craft projects.

The J. T. King chipped stone tools and lithic debris are dominated by chert raw materials, much of it from non-local sources. The Caddo that lived at the site apparently had ready access to Central Texas chert raw materials. It is suspected that the Caddo either had trade partners that lived in the Central Texas and east central Texas prairies from whom they obtained lithic raw materials and/or completed tools, or they had direct access to those raw material sources and/or tool makers, probably by horse travel. The Caddo in East Texas already had considerable numbers of horses by the mid-1680s.

\section{Timber Hill}

One of the more important sites of the ca. 1775-1838 period is the Timber Hill site (41MR211), or Sha'chahdinnih. It has been characterized by some as the "last village of the Kadohadacho Caddo in the Caddo homeland region" (Parsons et al. 2002:iii), although there were at least four other Kadohadacho villages in East Texas up to the fall of 1838. The principal Kadohadacho village in the early nineteenth century, and probably occupied until the early 1830s, Timber Hill was named after the first village founded after the Caddo emerged from the earth and left Cha'kani'na, the place of crying. The site was established on James Bayou in the Caddo Lake area in 1800, likely covered several hundred acres, perhaps 0.5 miles in diameter, and had at least 300 families living there during much of its existence. 


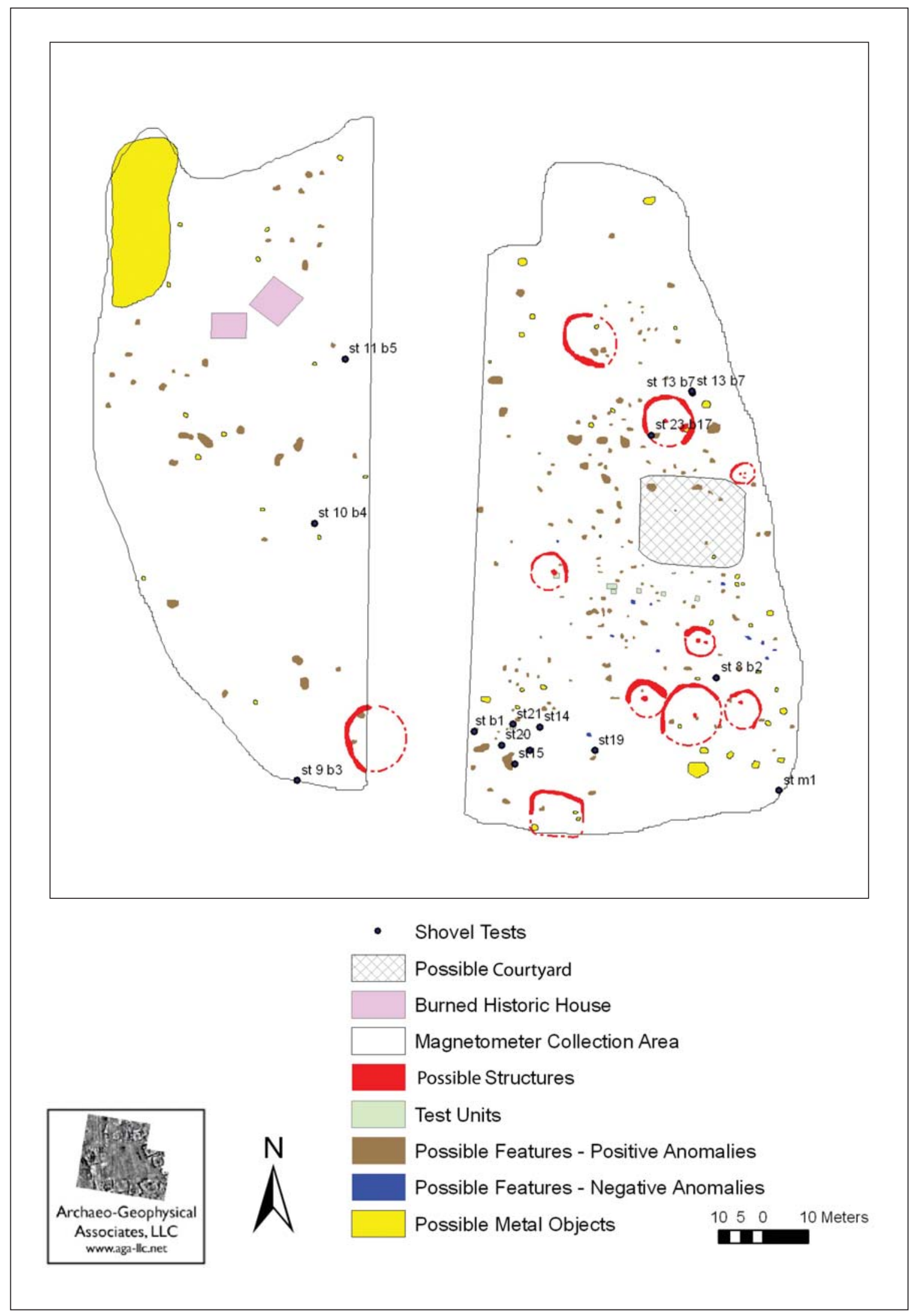

Figure 9. Interpretive map of the J. T. King site based on the magnetometer findings. 


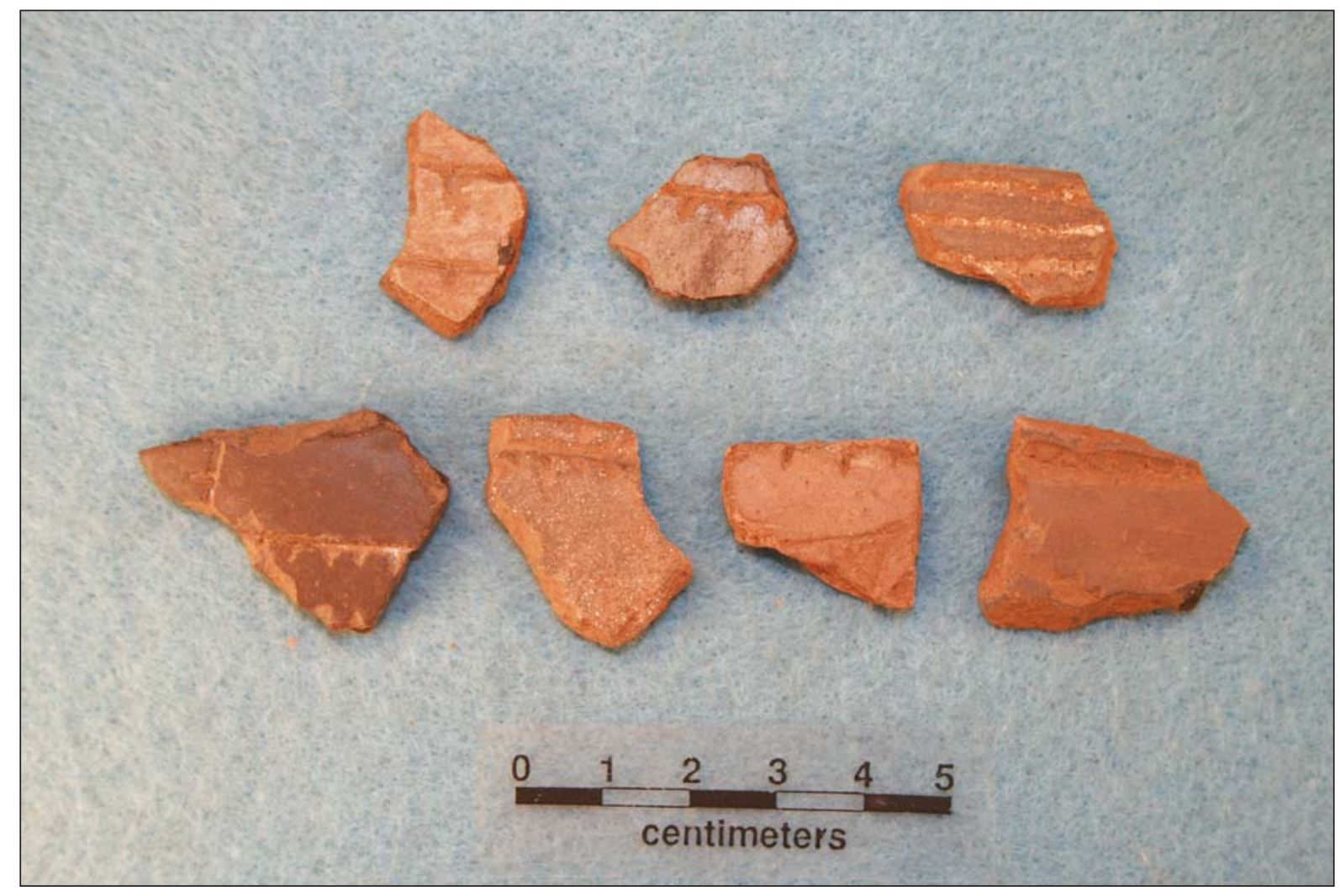

Figure 10. Patton Engraved sherds from the J. T. King site.

\section{Middle Caddo Village}

Another important — but still little known - Caddo site occupied in the first years of the nineteenth century is what is known as the Middle Caddo Village in East Texas. This is one of a number of Caddo villages probably established along the loose boundary between American Louisiana and Texas after the 1835 U.S. Treaty with the Caddo. As an 1837 petition from the Caddo to the U.S. government indicates, the Caddo purposefully established their villages outside the domain of the U.S.:

We have established our villages near the head of Lake Sodo [Caddo Lake] which we believe to be without the boundary of the United States, but on running the line between Mexico and the U.S. should it be found to be within the jurisdiction of the latter, we will instantly remove further to the west [into Texas]. Hope you will inform the President of our great wish to have this line run out as we can make no permanent settlement until this is done. (National Archives and Records Administration, Letters Received by the Office of Indian Affairs, 1824-1881. Roll 31, Caddo Agency, 1824-1842. Letters, Caddo Agency. Petition, Caddo Chiefs to Joel Poinsett, January 9, 1837).

The Middle Caddo Village was still in existence in early 1838. This village (41HS840) appears to cover about 40 acres, based on very limited investigations (primarily shovel testing and metal detecting). Items obtained in the market economy abound here, and include such trade goods obtained from nearby U.S. trade factories as gun parts and rifle balls (of several calibers) from muskets, gun flints, axe blades, iron kettles, case knives, horse gear, pearlware cups and plates, and wine bottle glass. There is evidence here of both blacksmithing and the on-site manufacture of rifle balls, and there are pieces or cut-outs of silver ornaments and copper sheet fragments that suggest the Caddo were manufacturing ornamental items from available trade metal sources. They also made sheet copper and iron arrow points. One of the square cut nails found 
here had evidence of use as a tool, as did pieces of chipped glass; chipped glass and ceramics were probably used as scrapers on deer hides, and such implements have been recovered from other ca. 1790-1835 Caddo sites. Caddo ceramic sherds are also present at the site, along with clay pipe sherds.

\section{Pueblo of Nacogdoches}

One site from the pueblo of Nacogdoches, re-occupied in 1779 by Gil Ybarbo and settlers at the site of the former Mission Nuestra Señora de los Nacogdoches (abandoned in 1772), contains both Caddo and European ceramics and other European goods (most notably glass beads and the bones of domestic animals) in contexts suggesting considerable interaction between Caddo groups living around Nacogdoches and the Spanish and Mexican settlers and ranchers throughout much of the market economy period. This is not surprising since Nacogdoches was at that time a local center of European commerce and trade. European ceramics found at this site included creamware and pearlware vessel sherds in abundance, as well as faience brune and Mexican majolica, and the sherds from reconstructable Caddo vessels; these vessels probably held items such as bear fat and corn traded and bartered with the citizens of Nacogdoches.

\section{Cultural Context}

\section{Caddo Territory}

Where the Caddo peoples differ from many of the other Native American groups that lived in Texas is in their known territorial stability. Their settlement and use of lands in what is now East Texas, Northwest Louisiana, Southwest Arkansas, and eastern Oklahoma has had great permanence: a thousand years or more living and sustaining themselves in the same broad forested and well-watered landscape of the western Gulf Coastal Plain. First visited by the De Soto entrada in 1542 in southwestern Arkansas and eastern Texas, the Caddo were described as having an occasionally dense but sometimes sparse population (dependent upon their location within rural or town communities) that lived in scattered settlements with abundant food reserves of corn. Archaeological investigations confirm that Caddo communities were widely dispersed throughout all of the major and minor river valleys of the region from at least A.D. 800 until the early 1800s.

Looking more closely at the historic territory of the "Great Kingdom of the Tejas," about 1520/1530, the Hasinai Caddo groups lived in permanent communities throughout the upper Neches and Angelina river basins. They are represented archaeologically by the Frankston (ca. 1400-1600) and Allen (ca. 1600-1840) phases of what archaeologists call the Anderson Cluster (Figure 11). Although occasional Hasinai Caddo groups or bands lived west of the Neches and Trinity rivers in historic times, they usually did not go beyond that boundary, "unless going to war," according to Henri Joutel, a chronicler of the La Salle expedition. The Hasinai groups continued to live in the upper Neches and Angelina river basins until they were driven out of East Texas by the Republic of Texas after 1836 .

European maps of the late 1500s to the mid-1600s located Caddoan groups such as the Naguatex, Nisoone (Nasoni), Pato, Lacane, Ays, Xualatino (or Soacatino), and Guasco on a western tributary of a drainage labeled Rio de Leon or Rio de Spiritu (Espiritu) Santo, the Mississippi River, but it is clear from similarities between 1572 and 1656 maps that geographic knowledge of the territory by Europeans of the interior-living Caddo and other Texas tribes had not changed or improved over that period. It was not until Europeans (principally La Salle) ventured again into the Caddo area in the 1680s that the territory of the various Caddo tribes, and their non-Caddo allies and enemies, became better understood.

Delisle's map of 1702 places a series of related Caddo groups along a considerable stretch of a western tributary of the Mississippi River, obviously the Red River. Beginning on the lower Red River with the Nachitoches [Natchitoches] and proceeding up river, other Caddo groups included the Nakasa (one of the enemies of the Kadohadacho in 1687, according to Joutel), Yatache [Yatasi], Natsoos [Nanatsoho], Cadodaquiro [Kadohadacho], the [upper] Nachitoches, and the Nassonis [Nasoni]. Upstream from them on 


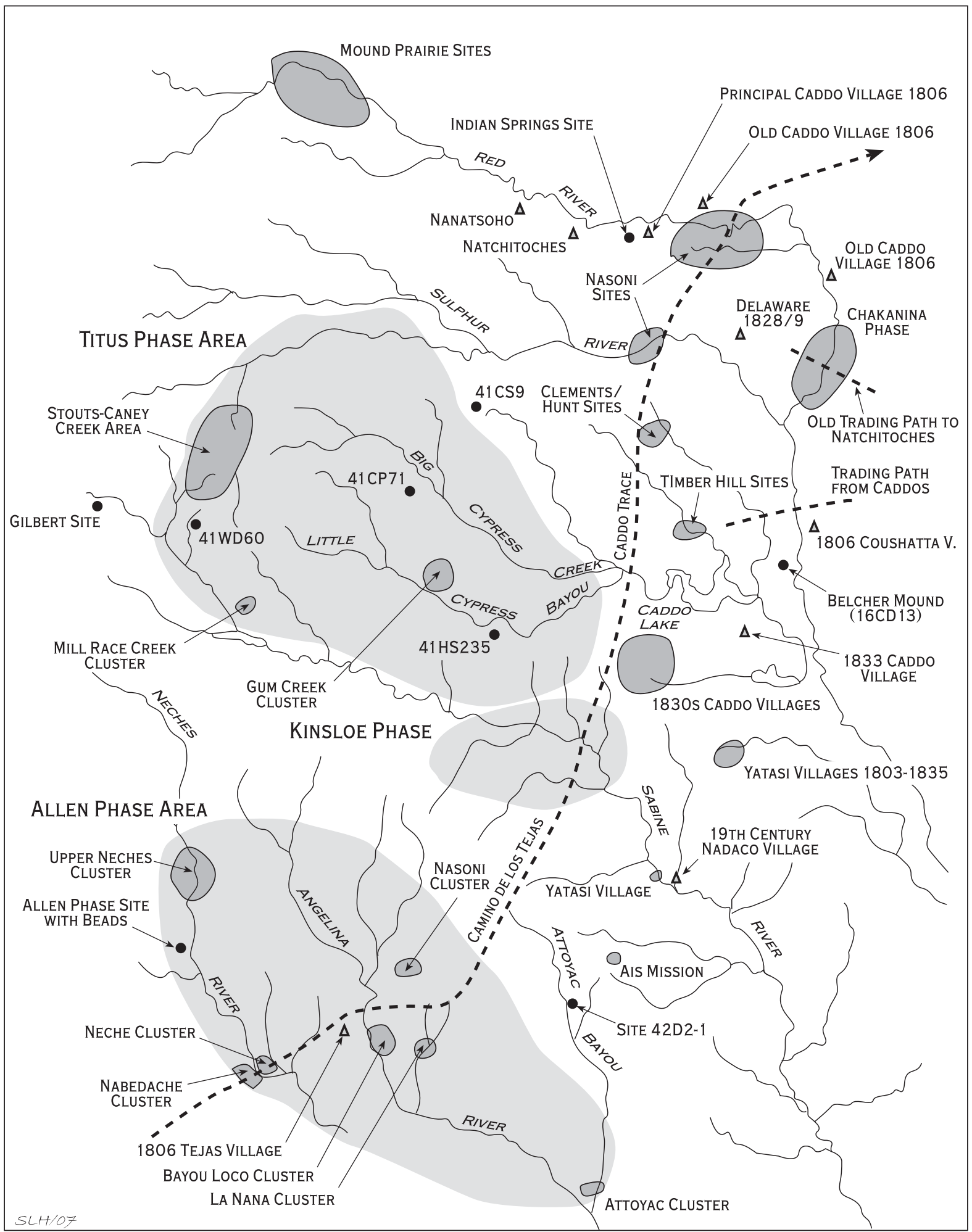

Figure 11. Historic Caddo sites and phases in East Texas, southwest Arkansas, and northwest Louisiana. 
the Red River were the Canouaouana and Chaquanhe tribes, apparently enemies of the Kadohadacho, again according to Joutel.

The westernmost Caddo groups were shown by Delisle as living on and near the Rio aux Cenis (probably the Neches River), Cenis (or Senys) being the French name for the Hasinai Caddo. Other than the mistake of having the Rio aux Cenis running into the Red River, Delisle's map indicates that the French had a good understanding of the locations of the various Hasinai Caddo groups, from the Inahe [Hainai] to the east (on the Angelina river), the Nadaco and Nassonis [Nasoni] to the north and west, and a series of Cenis or Hasinai communities along the western boundaries of their territory. No Caddo communities were depicted west of the Trinity River (Rio Baho), with the closest non-Caddo communities living between the Trinity and Brazos (La Maligne R.) rivers. On the Brazos River lived the Canohatino tribe, one of the enemies of the Hasinai Caddo. That tribe felt the brunt of a French-Caddo attack in 1687 where more than 40 Canohatino were massacred by the joint, armed forces.

By the 1750s, the Europeans had a much better perception of the location of the Hasinai Caddo groups and related Caddo tribes in East Texas and western Louisiana. This is not surprising considering that there was a French trader reported to be living at each of the Caddo settlements, even those in the province of Texas. In a 1757 French map, Caddo groups were shown as being dispersed from east of the Sabine River (Rio Zavinas), near the Spanish presidio at Los Adaes, to just west of the Neches River (Rio de Nechas), with Spanish missions in their midst at Nacoudoches [Mission Nuestra Senora de los Nacogdoches] and de los Hays [Mission Nuestra Senora Dolores de Ais].

Between the 1750s and the 1780s, the Tawakoni, Yscani, and Kichai tribes, affiliated Wichita-speaking tribes, had moved south and settled in large villages along the margins of the Post Oak Savanna, in traditional Caddo hunting territory. The Hasinai Caddo tribes and the Wichita groups were strong allies, and the Caddo leaders were of great assistance in concluding formal and peaceful relations between the Wichita-speaking tribes and the Spanish in 1771-1772, and again between the Caddo, the Wichita-speaking tribes, and the Republic of Texas in 1843. The Bidai tribe, also allies to the Hasinai, lived to their south along the Trinity and Neches-Angelina rivers.

Because of the outbreak of epidemics at the Spanish settlement of Nacogdoches in the late 1770searly 1780s, the Nadaco Caddo moved along the Caddo Trace to resettle on the Sabine River, where they remained until the establishment of the Republic of Texas. The Kadohadacho groups, with populations also diminished by epidemics, by this time had coalesced into one village for protection against the Osage, and relocated by 1795 along a small tributary feeding into Caddo Lake, a natural lake formed by the Great Raft along the Red River valley. Most of the Kadohadacho remained in the Caddo Lake area until 1842, while others had moved into Indian Territory shortly after 1836, or had settled in the upper Trinity River drainage.

The Hasinai Caddo groups - the Nacogdoche, the Hasinai, and Nabedache (or Tejas) - remained in their East Texas homelands, living in the early 1800s outside of the Spanish settlement of Nacogdoches, west then to the Neches River, and north of the El Camino Real. Immigrant Indians pushed west, including the Biloxi, Alabama, Coushatta, Choctaw, and Cherokee, and they began to settle within traditional Caddo territory, both north and south of Nacogdoches, as well as along the Red River north and east of Caddo Lake. The Alabama and Coushatta people asked for, and received, the permission of the Kadohadacho caddi to resettle along the Red River, and they became strong allies of the Caddo peoples. This was not the case with the Choctaw, as conflicts between them and the Hasinai Caddo over hunting territories began almost immediately after the Choctaw moved in numbers into East Texas. Later, however, the Choctaw allied with the Caddo peoples and the Cherokee in war parties against the Osage. 


\section{Interaction with Friends and Strangers}

No Caddo communities, towns, or mound centers were ever fortified, and there is virtually no evidence in the archaeological record for warfare or violent conflict between the Caddos and other peoples. That is, evidence of individuals dying from wounds inflicted from an arrow point, scalping, or forms of mutilation after death are rare indeed, and certainly very rare when compared to what has been detected in the archaeological record among contemporaneous Indian groups in the Southern Plains and in parts of eastern North America. This is also quite a contrast with the sedentary agriculturists living in the Mississippi Valley and interior Southeast, where heavily populated towns were palisaded, and Indian polities asserted political and economic authority through warfare. The widely dispersed prehistoric and historic Caddo communities do not hint of a defensive posture.

This is not to say that there were not conflicts between the Caddo peoples and their neighbors. Indeed, French and Spanish documents of the 17th and 18th centuries clearly show that the Hasinai and the Kadohadacho had many enemies, some of long-standing like the Chickasaw, Lipan Apache, and Osage. For their other enemies, it is suspected that relations between them and Caddo peoples alternated over the years between alliances and hostility, depending upon the needs of the moment, particularly the willingness to trade. All this was to change with the appearance and adoption of the horse and gun among the Caddo and their Southern Plains neighbors.

By the 1680s, those hunting-gathering groups to the west and southwest of the Hasinai Caddo tribes had horses in numbers, but lacked guns, which the Caddo peoples began to obtain (if sometimes only periodically) in trade with the French fur traders. The Hasinai Caddo peoples also had horses obtained through trading with their allied groups on the prairies and plains of Central and southern Texas, and through raiding on their enemies. The Caddoan groups were well placed along the "Horse Frontier" and the "Gun Frontier," and as of about 1716, the Hasinai and the Kadohadacho marked, respectively, the frontier of horses moving eastward, and of muskets moving westward in trade.

This accessibility of such desirable goods as guns and horses contributed strongly to the maintenance and expansion of Caddo social and political power relationships among their Native American neighbors, allies, and enemies. With the horse and gun, the Caddos were able to increase their bison hunting in the prairies and plains well west and southwest of their territory, which probably exacerbated existing animosities, but did not prevent them from moving into and using new areas (i.e., new hunting territories and in settlements astride Indian and European trade routes). It also assured the Caddo peoples of continued trade with the Europeans, and thus an active role in arranging political and economic measures between other Native Americans and the Europeans that directly affected their well-being.

Fighting between the Caddo and their enemies mainly consisted of hit-and-run raids upon an enemy, in which an attempt was often made to capture a foe, rather than battles with large numbers of casualties on either side. This enmity did not prevent the Caddo peoples from hunting and trading regularly in areas outside of Caddo territories before and after they had the horse, as noted above, and indeed the Hasinai Caddo peoples were quite familiar with these regions, giving Fray Mazanet in 1691 their names for each of the streams from the Nabedache village on San Pedro Creek (just west of the Neches River) as far west and south as the San Antonio area. After the Caddo peoples had horses, they began to regularly use Central and South Texas as hunting territory, obtaining deer and bison hides for trade with the French.

For the Kadohadacho tribes, on the other hand, according to Joutel in 1687, "most of the hostile tribes are to the east...and have no horses; it is only those towards the west which have any." The hostile tribes to the east had plentiful supplies of guns obtained from both French and British sources, and their aggressive raids focused on obtaining Caddo slaves, horses, and furs.

This disparity in supplies of the coveted horses and guns led to a profitable trade for the Caddo peoples, either in direct exchange or acting as middlemen, but over the long-run, the trade bounty did not serve to better 
protect them against the Osage, or the Chickasaw, also well-supplied with guns, who, from the late 1600s to the early 1700 s, ceaselessly raided the Caddo for slaves. Shortly thereafter, the Caddo became involved in the thriving traffic in Apache slaves, one outcome of the Southern Plains warfare between the Comanche and Apache that began about 1700, trading European goods for Apache children at the French and Spanish markets at Natchitoches and Los Adaes. By the 1760s, the Osage were expanding their hunting and trapping territory to obtain more furs, however, and their depredations against the Caddo changed to a seemingly war of conquest. The Osage succeeded in eventually forcing the villages of the Kadohadacho tribes to coalesce from five villages to one over a period of about 80 years, and then along with the Yatasi, the Kadohadacho moved far down the Red River and closer to the European post and fort at Natchitoches, abandoning the Great Bend area, in a desperate attempt to escape the aggressive expansion of the Osage tribe.

\section{Diseases and Epidemics}

With respect to the interaction between Europeans and Caddo peoples, of primary consideration are the effects of that contact on the nature of changes in Caddo societies. The population and disease effects on native Caddo groups have been closely scrutinized employing both archaeological and bioarchaeological evidence. The work has concentrated especially on reconstructing Caddo population histories; determining when epidemic diseases were introduced among Caddo groups; when post-contact population declines occurred; and what were the long-term cultural impacts of disease and population declines on Caddo societies and communities. Attention has also been devoted to examining trends and discontinuities in those aspects of the Caddo archaeological record - such as abandonment of regions and major sites, the appearance and role of community cemeteries among some Caddo communities, or the discontinuation of mound building - that in certain circumstances seem to relate to cultural changes in demographic or health conditions.

A bioarchaeological study of the Ouachita River basin in southwestern Arkansas, the most comprehensive bioarchaeological study of post-1500 Caddo skeletal remains completed in the last few years, seems to suggest that between 1500-1600, Caddo adults lived shorter lives than before, and that infection rates among sub-adults and adults were higher than at any other time in the Caddo occupation of the basin. Might this evidence reflect population declines due to European diseases? The archaeological record suggests otherwise, as the evidence from such sites as Hardman indicate that the Caddo communities were flourishing in the Ouachita River basin about this time, due in no small measure to an expansion in the salt trade with Native Americans in the lower Mississippi Valley. After 1600, however, infection rates declined and adult age at death increased, which has been attributed to improved adaptive efficiency among these Caddo populations; after 1700, however, the Caddo groups completely abandoned the Ouachita River basin.

With one exception from a Caddo site in southwest Arkansas, there is no direct bioarchaeological evidence that we are aware of for the presence of epidemic diseases such as smallpox or measles in Caddo historic bioarchaeological assemblages. However, acute epidemic diseases rarely leave specific direct evidence on archaeologically-recovered skeletal samples, limiting in this respect the interpretive significance of bioarchaeological remains to address the issue of disease impacts straight-on. Nevertheless, the further study of Caddo bioarchaeological remains from post-1500 sites can contribute important new information on the overall health, demography, and diet of Caddo populations in the contact era.

There is no question that European epidemic diseases among the Caddo peoples resulted in regional population declines (certainly noticeable after 1691), group movements, and the eventual coalescence of once-separate Caddo bands. It has been estimated that Caddo populations declined an estimated 75 percent in size between 1687 and 1790 due to epidemics. Population declines and settlement changes appear to have been more substantial in communities along the major rivers, as seen by the complete abandonment of the Ouachita and Little rivers by 1700, and the Arkansas River earlier in the 1600s, but there was no major abandonment of East Texas by the Hasinai Caddo in historic times. Regional population decline and abandonments, in conjunction with the coalescence of disparate groups, are likely the major impetus for the development of the Kadohadacho, Hasinai, and Natchitoches confederacies (Figure 12). 


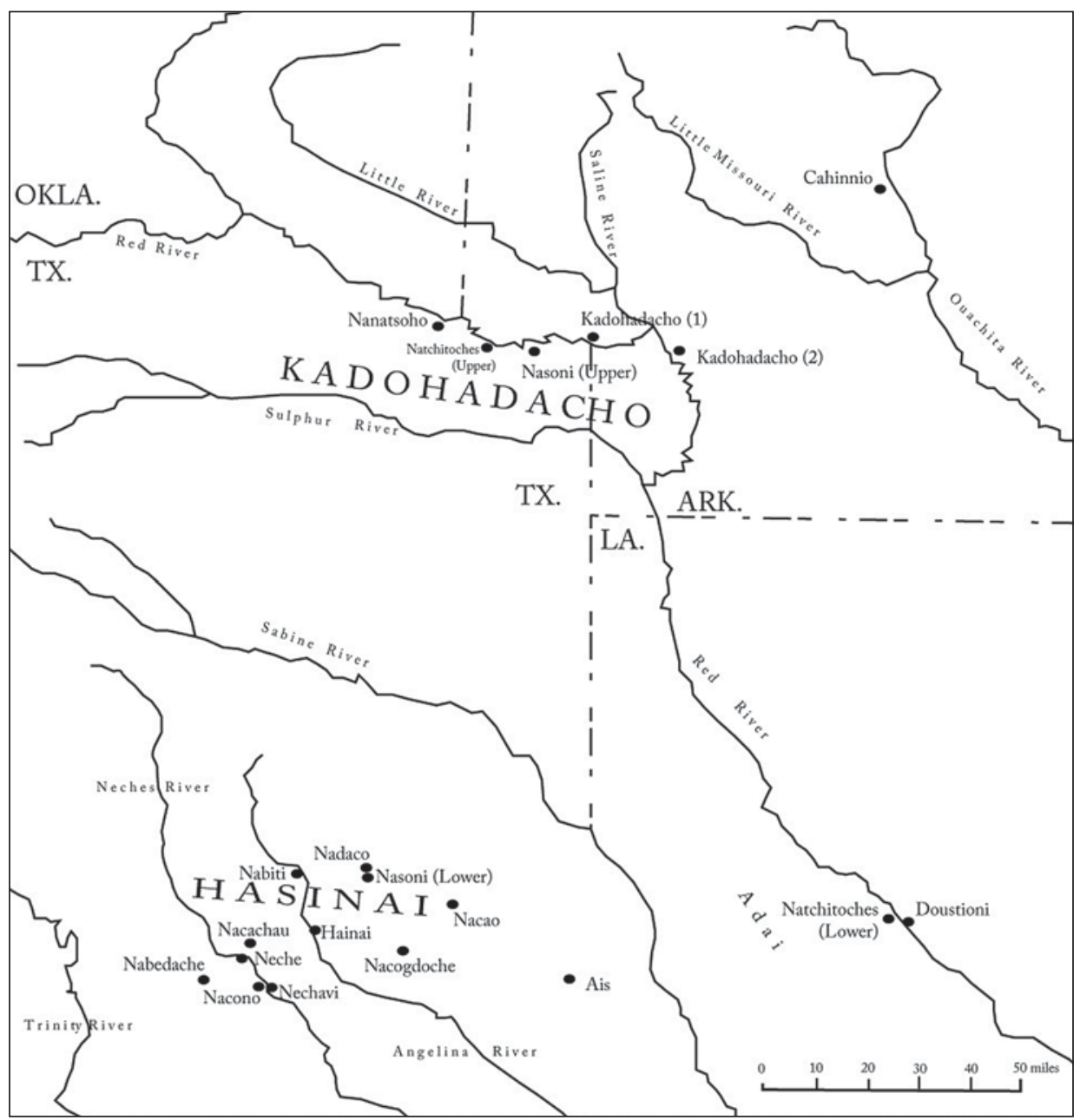

Figure 12. Locations of the Hasinai, Kadohadacho, and Natchitoches confederacies and communities in East Texas, southwest Arkansas, and Northwest Louisiana (after Swanton 1942).

While the establishment of the Spanish missions failed completely to convert the Caddo peoples, or led to the resettlement of Caddo communities around the missions, some Caddo apparently chose mission life rather than remain in East Texas. A few Eyeish (Ais) and Tejas (Hasinai) individuals were enrolled at missions San Jose and Valero in San Antonio in the mid- to late 1700s.

\section{Participation in the Fur Trade and other Historic Caddo Relationships}

The Caddos' participation in the fur trade had important consequences for them, as well as for their European partners in the trading system. As with the fur trade elsewhere in North America, the participation of the Caddo led to their acquiring and accumulating large quantities of desirable goods, which they in turn exchanged with other Indian groups for furs and horses, all the while exploiting existing trade networks to their advantage. The success of the fur trade for the Caddo also allowed them to expand their hunting activities into new territories, and/or reoccupy abandoned river valleys (such as the upper Sabine River basin after about 1740) for the same purposes. Their contributions to the European frontier economy, and their military presence, were recognized by the French and Spanish governments through their program of annual gifts and presents, reflecting the existence of political and economic commitments between the Caddo peoples and the Europeans. These all had considerable economic, military, and social values to the Caddo peoples in their dealings with other Indian groups. 
Other studies have focused on how historic Caddo societies and socio-political relationships were transformed, while also examining how key cultural concepts and symbols of sacred and secular rituals and ceremonies were maintained, amidst the European presence. George Sabo's ethnohistorical studies of late 17th and early 18th century Caddo societies in East Texas have shown how significant structural relationships within Caddo society — such as village organization and the hierarchical ranking of peopleswere explicitly extended to Europeans, thus drawing them within their world and scope of understanding, giving the Caddo a means to absorb and manipulate the Europeans. Sabo uses symbols of sacred and secular Caddo rituals and greeting ceremonies to draw out these relationships, as such rituals and ceremonies gave Europeans positions and statuses within indigenous social systems. By means of such relationships, the Caddo were able to extend to their relations with Europeans those basic principles and themes that ordered and gave shape to their own distinctive societies. Caddo rituals and greetings seem to dominate much of the Spanish and French archival documents, puzzling the European observers with their effusiveness, but are sadly missing from the observations and records of the Americans, strongly hinting at the inability of the Caddo by the 1810 s to exploit existing American trade and military relationships.

New historical studies of the Caddo are considering the social and political character of the Hasinai and Kadohadacho, two of the Caddo confederacies in historic times (the other being the Natchitoches), following in the tradition of historians and ethnographers such as Herbert E. Bolton and John R. Swanton who pursued Caddo historical research in the early 1900s. These studies are crucial to understanding the early historic (pre-1835) archaeology of the Caddo peoples, as is the continued archaeological study of such early 19th century Caddo sites as Timber Hill site near Caddo Lake (Figure 13). Other historians are focusing on the routes of European explorers in Caddo country, helping to locate important Caddo villages, tribal areas and aboriginal trails, as well as fleshing-out economic and political relationships between the Caddo, other Native American groups, and with Europeans. These studies make evident the vibrant and dynamic nature of Caddo lifeways from prehistoric times down to the present-day, and the impressive social and cultural complexity and diversity that characterizes Caddo Native history.

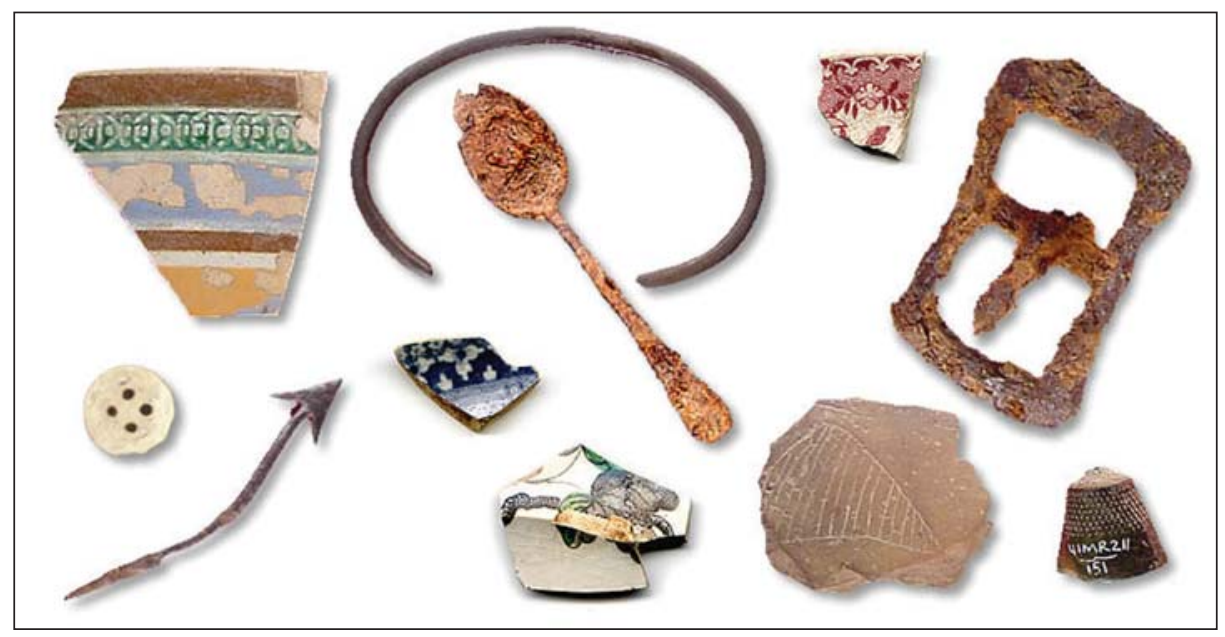

Figure 13. A range of artifacts of European and Caddo manufacture recovered during Texas Historical Commission excavations at the Timber Hill site (41MR211).

As previously noted, the powerful, agricultural Caddo chiefdoms were recognized as the "Great Kingdom of the Tejas" by the Spanish and French in the 17th and 18th centuries, who they chose to accommodate and cooperate with when it was to their advantage, while they introduced them to their own sacred and secular rituals. Even in the early part of the 19th century, the Caddo political leaders (such as the caddis Tinhiouen, Dehahuit, and Iesh or Jose Maria) were still recognized as politically astute and masterful mediators and alliance-builders between European and Anglo-American explorers and colonists, as well as with Native American groups such as the Comanche, Wichita, and Apache tribes. 


\section{Relocation and Removal}

With the permanent Anglo-American settlement of the region in waves of immigration after about 1815, it was the Caddos' misfortune to have been living on choice and fertile farmlands desired by the Anglo-Americans. In a few short years, they were dispossessed of their traditional homelands by the U.S. and Texas governments, their lands and goods swindled from them by U.S. Federal Indian agents in the Caddo Treaty of 1835, and eventually they were forced in 1859 to relocate from the Brazos Reserve in Texas to the Wichita Agency in western Oklahoma (then Indian Territory) (Figure 14). Shortly thereafter, they were caught up in the Union and Confederate struggle for the Indian Territory during the Civil War, and with little trust for either the rebel or federal governments, the Caddo tribe abandoned their lands in Indian Territory for lands in Kansas. To date, there is a virtual absence of archaeological data from these Caddo Indian settlements, or on the 1860s and later Caddo settlements in western Oklahoma and Kansas. This is one of the great challenges in the years ahead: it remains to archaeologists to actually identify these Caddo settlements, which should contain significant and unique information on Caddo lifeways during a period of heightened acculturation and material culture changes.

Between about 1836 and 1842, the Hasinai, Nadaco, and Kadohadacho tribes had all been forcibly pushed out of East Texas, some moving into Indian Territory, while others moved west into the upper Brazos River drainage. This was the final and bitter end to the Caddo settlement of their traditional homelands. Though the Caddo groups made a successful agricultural living for a few short years in the hard but seemingly fertile lands of the Brazos River valley, they were never secure from Anglo-American encroachments, even when settled on the Brazos Reserve. They were compelled in 1859, according to John R. Swanton, noted ethnologist at the Smithsonian Institution, "to abandon their homes, the fruit of their labors, and the graves of their kindred," and were removed to the Washita River valley in Indian Territory.

Cecile Carter has related present-day Caddo thoughts, rituals, and ceremonies to highlight the strong and pervasive continuities from the Caddo's past to modern times, even during times of conflict. Her discussion of the Turkey Dance among the modern Caddos, when juxtaposed with the description of the Caddo women dancing the victory dance for Henri Joutel and his French companions in 1687, make clear how the victory dance then, and the Turkey Dance now, were and are used by the Caddo to celebrate their survival, plus retell history and carry messages from the past.

Similarly, when she talks about the special place of "that kind of pole" (Itcha kaa-nah) in the context of the Ghost Dance rituals among the Caddo in the 1890s, and the use of a similar kind of wood pole among the Nabedache Caddo in 1690, our understanding of the long-standing and continued importance of tobacco, fire, and smoke to Caddo religious rituals and ceremonies in prehistoric and historic times is broadened. We also think of the powerful influence of John Wilson (Nishkantu or "Moonhead") of the Caddo in the rise and spread of the peyote religion among Native American tribes on the Southern Plains in the 1880s, and his religious influence compares favorably to the influence and negotiating tenacity of Caddo leaders like the caddices Tinhiouen (from ca. 1760-1789) and Dehahuit (from ca. 1800-1833) of the Kadohadacho, and Iesh or Jose Maria (from about 1842 to 1862) of the Anadarko or Nadaco tribe.

Further insights into the traditional character of Caddo life bring out and pinpoint important historic period changes in their ritual beliefs and political practices. For instance, Father Gaspar Jose de Solís noted in 1768 among the Nabedache, the westernmost of the Hasinai Caddo tribes, that a Caddo women called Santa Adiva was the principal authority, instead of the xinesi and caddi, hereditary male leaders. Such a change was likely related to the effects of epidemics that had decimated Hasinai villages after the coming of the missionaries, as well as to the Spanish policy of presenting the staff of leadership to an elected leader, rather than following the then unbroken hereditary chain.

In the larger context of Caddo society, however, the hereditary chain of Caddo leadership — strong, peaceand alliance-building caddis - seems to have continued unbroken among the Hasinai and Kadohadacho; 


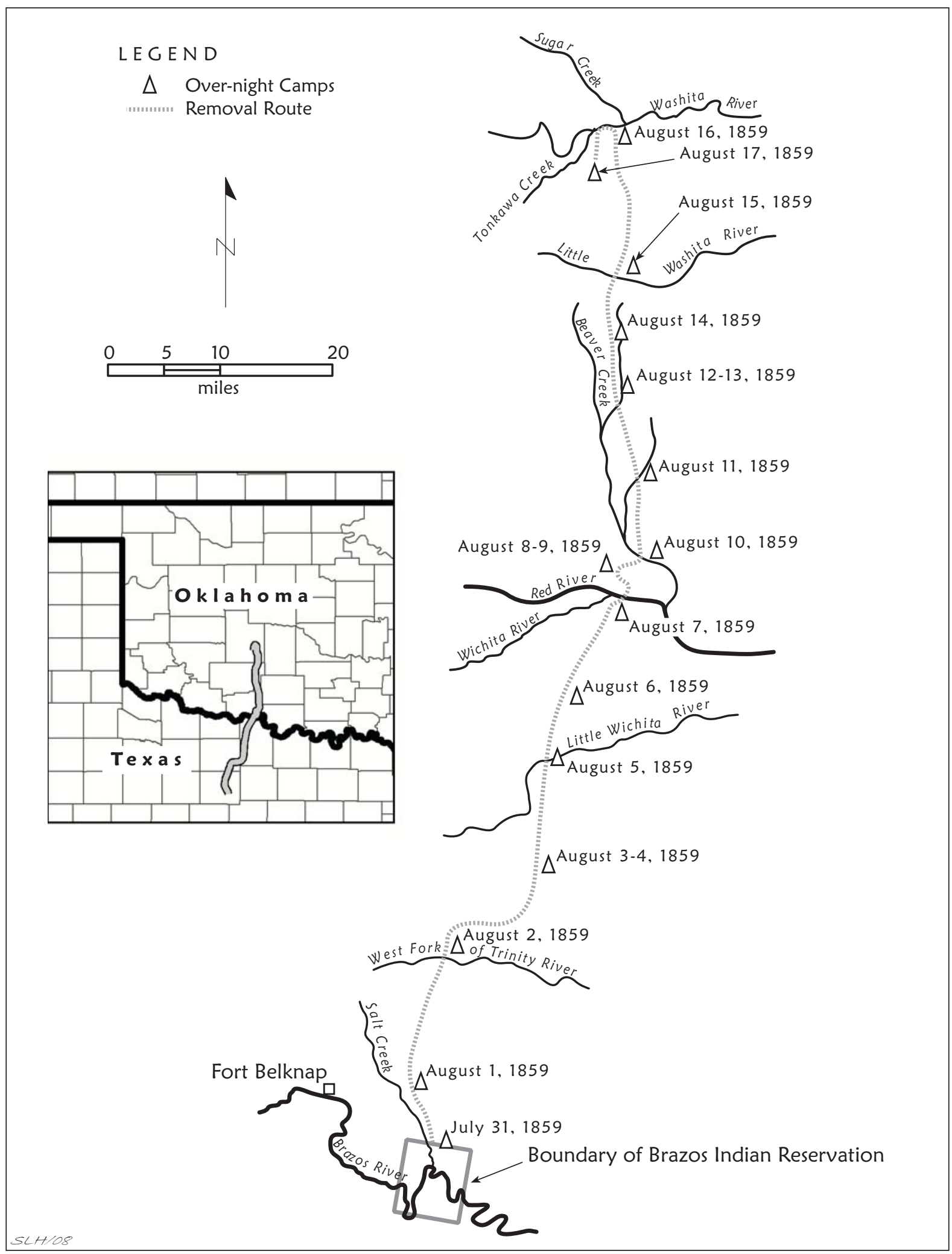

Figure 14. Removal trail of Caddo peoples from the Brazos Reserve to Indian Territory in western Oklahoma. 
this ultimately was the source of their strength. From European and American accounts, it is clear that the Caddo political leaders played important and influential roles in shaping the major political decisions of the day to favor the Caddo peoples, decisions that affected other Native American groups and Europeans, and in arranging and bringing to fruition alliances between the Caddo, powerful Native American groups like the Comanche and Wichita tribes, and European nations.

In the face of ever increasing conflict and contact in the early historic period, the Caddo peoples experienced devastating population losses from epidemic diseases, an estimated 75 percent between 1687 and 1790, group amalgamations, increased hostilities from slave-raiding Osage warriors, territorial abandonments and group movements, fundamental changes in trading prerogatives, and a forced removal from their ancestral homelands. Nevertheless, the Caddo peoples survived, with a powerful influence over other Native Americans in Texas during much of that time. Their survival called on all their religious faith, their political strength, influence and leadership, and their continued traditions and beliefs. We have much to learn from them still. The cultural and oral traditions of the Caddo peoples remain vibrant. So too do archaeological and historical studies of the Caddo.

\section{Peyoteism and the Origins of Caddo Religious Thought}

Peyote (Lophophora williamsii) has long been a sacred medicinal plant to a number of tribes across the United States. The Caddo Indians have a distinguished and long history of using this important plant. John Swanton (1942:121) noted:

It is interesting to remember that peyote was used by medicine men among the Hasinai at the beginning of the eighteenth century, and recalling the elaborate ritualism of the Caddo, as well as their various contacts with Christian missionaries, including the presence among them of established missions for three decades, one wonders whether such a background does not constitute part of the explanation of John Wilson. It may put the ancient fire cult of the Natchez and Caddo, Franciscan teachings, the Ghost dance religion, the peyote cult, and the North American churches founded on the last mentioned in one line of descent.

The Caddo Indians practiced a vibrant peyote religion long before John Wilson (Moonhead) or Quanah Parker re-ignited the Native American Church. Moreover, research has shown the importance of the peyote plant to the Caddo long before any European contact. The peyote religion at the time of the Spanish missions in Texas was full of songs and dances in honor of one known today as $A ? a h$ ? hi-u kuu-i$-h a$ or Father Above, translated to mean home where God lives. Although Swanton proposed that the Hasinai medicine men used peyote "at the beginning of the eighteenth century" (a reference to Friar Hidalgo's Spanish account) how long had they been using this plant before any written records?

In Swanton's analysis of the history of the Caddo Indians, he recognized that during the contact period with the Spanish and the establishment of Spanish missions in East Texas that the Caddo did not convert to Catholicism as hoped, because they had a long standing tradition of worshiping their God in their own way. Although the Caddo have long been referred to as being a part of a perpetual or eternal "fire" cult " $e$ 'but $n i-k u u$ " (literally grandfather fire), the fire was only a small part of the ritualism, the peyote or "sik' $u h-h o$ " (from the literal meaning "rock") has long been the central foundation for the religion.

Ethnohistorian Mariah F. Wade in her translation of a November 4, 1716 letter from Fray Hidalgo to the Viceroy of New Spain recognizes this as well and emphasizes several important points in her "Introduction" to the translation: (1) The Caddo refused the religion of the Friars and the Catholic Church and (2) That "researchers have not completely understood the essence of this refusal nor the strength of Caddo religious practices and convictions." Her translation goes on to describe Friar Hidalgo's biased but pertinent viewpoints regarding the Hasinai Caddo: 
As far as we have determined all this Nation is Idolater, they have houses of Adoration and they have the perpetual fire, which they do not let be extinguished. They are very superstitious, and they will believe the visions related to them by the Indian male and female who gets drunk on the peyote, or the small bean, during the Dances that they hold. They prepare this drink specifically for the celebrations...

One interesting note is that Swanton refers to the use of peyote by "medicine men," when clearly by the earliest written accounts, both "male and female" used peyote. With this in mind, Caddo women have often been attributed as being the manufacturers of Caddo ceramic vessels and their decorative motifs. Could some of the beautiful, geometric, and unifying motifs found especially on Caddo fine ware ceramics be suggestive of their ceremonial use of peyote and these types of "celebrations" described by Friar Hidalgo?

\section{Everyday Things: The Character of Early Historic Caddo Ceramics}

The most distinctive material culture item of the Caddo groups living in East Texas were the ceramics they made for cooking, storage, and serving needs. The styles and forms of ceramics found on sites in the region hint at the variety, temporal span, and geographic extent of a number of ancestral Caddo groups spread across the landscape. The diversity in decoration and shape in Caddo ceramics is substantial, both in the utility ware jars and bowls, as well as in the fine ware bottles, carinated bowls, and compound vessels.

The Caddo made ceramics in a wide variety of vessel shapes, and with an abundance of well-crafted and executed body and rim designs and surface treatments. From the archaeological contexts in which Caddo ceramics have been found, as well as inferences about their manufacture and use, it is evident that ceramics were important to the Caddo in: the cooking and serving of foods and beverages, in the storage of foodstuffs, as personal possessions, as beautiful works of art and craftsmanship (i.e., some vessels were clearly made to never be used in domestic contexts), and as social identifiers; that is, certain shared and distinctive stylistic motifs and decorative patterns marked closely related communities and constituent groups. These kinds of ceramics were designed to serve different purposes within Caddo communities and family groups-from that of a cooking pot to the mortuary function of a ceremonial beaker - and this is reflected in differences in paste, surface treatment, firing methods, decoration, and vessel form between the two wares.

The post-A.D. 1400 Caddo fine ware designs in East Texas included scrolls, scrolls with ticked lines, scrolls and circles, negative ovals and circles, pendant triangles, diagonal lines and ladders, and S-shaped motifs. These kinds of decorative elements continued in use in historic Caddo ceramics (that is, until about A.D. 1800 or later). They are best exemplified by the intricate scrolls, ovals, and circles on Hudson Engraved and Keno Trailed bottles and Natchitoches Engraved bowls among Red River Caddo groups; the scrolls and ticks of Patton Engraved among Hasinai Caddo groups south of the Sabine River (see Figure 10); and the pendant triangles and engraved scrolls on Womack Engraved bowls on the upper Sabine and the middle Red River (see Figure 6). In historic Caddo times, ceramic vessel forms and decorations are considerably more homogeneous across much of the Caddo area, suggesting extensive intra-regional contact between contemporaneous Caddo groups.

\section{Caddo Archaeology in Late Eighteenth to Mid-Nineteenth Century Times}

Sustained contact between the Caddo peoples and the Spanish, French, Mexican, Texan, and American governments brought European trade materials and technology in tandem to Caddo peoples with the social objectives and policies of these foreign polities, many aimed at replacing Caddo cultural identity under the guise of religious conversion, trade, and participation as consumers in a burgeoning market economy, albeit one of relatively small scale at the time. Ultimately, the aim of dispossession of Caddo lands was achieved by Texans and Americans, who sought these rich lands in what became Arkansas, Louisiana, Oklahoma, and Texas. However, under the strong leadership by various caddices, who relied on long- 
standing commonalities and alliances between kin-related Caddo groups and families, and an appreciation for trade and exchange that was before now solidly based on kin and gender relationships and reciprocity, these Caddo groups and families were able to coalesce as the primary means of maintaining their cultural identity and assuring their survival in a chaotic world. Although the population of Caddo groups continued to decrease because of the continued introduction of European epidemic diseases as time passed-from ca. 28,000 in the late seventeenth century to about 500 people when they left the Brazos reserve in the summer of 1859 (Table 1) - they continued to be important participants in the Texas and Louisiana market economies through the 1830s. For example, upon a request from the United States to allow other tribes to enter their lands, in effect asking that they share their limited resources, the Caddo demanded compensation. Dehahuit stipulated that an annuity be paid in return for allowing other tribes to reside alongside the Caddo (Carter 1995:259). Cultural identity was built on the strength of Caddo relationships to their land, and they insisted upon fair treatment in the frontier market economy, as long as they were able to hold onto those lands. Everything changed for the Caddo peoples after 1835.

Table 1. Caddo populations through the Colonial era.

\begin{tabular}{|c|c|c|c|}
\hline Year & Source & Warriors* & Population \\
\hline \multicolumn{4}{|l|}{ Hasinai } \\
\hline 1699 & Pierre Talon & $600-700$ & $2400-2800$ \\
\hline 1716 & Ramon & & $4000-5000$ \\
\hline 1721 & Aguayo & & ca. 1378 \\
\hline 1779 & De Mezieres & 135 & 540 \\
\hline 1783 & Morfi & $380(?)$ & 1520 \\
\hline 1805 & Sibley & 200 & 800 \\
\hline $1818-20$ & Cincinnati Gazette & 150 & 650 \\
\hline 1820 & Padilla & & 1450 \\
\hline 1828 & Terán & 23 & 92 \\
\hline 1828 & Berlandier & $30-40$ & $120-160$ \\
\hline 1834 & Almonte & & 400 \\
\hline 1836 & Republic of Texas & & $200 \#$ \\
\hline 1847 & Burnet & 200 & 800 \\
\hline 1851 & Stem & ca. 100 & ca. 315 \\
\hline \multicolumn{4}{|l|}{ Hainai } \\
\hline 1783 & Morfi & 80 & 320 \\
\hline 1798 & Davenport & 60 & 240 \\
\hline 1809 & Salcedo & 60 & 240 \\
\hline 1828 & Berlandier & 10 & 40 \\
\hline \multicolumn{4}{|c|}{ Nabedache } \\
\hline 1779 & De Mezieres & 40 & 160 \\
\hline 1783 & Morfi & 40 & 160 \\
\hline 1798 & Davenport & 80 & 320 \\
\hline 1819 & Padilla & & 500 \\
\hline 1828 & Terán & 15 & 60 \\
\hline 1828 & Berlandier & 80 & 400 \\
\hline \multicolumn{4}{|c|}{ Nacogdoche } \\
\hline 1783 & Morfi & 300 & 1200 \\
\hline 1798 & Davenport & $50^{* *}$ & 200 \\
\hline 1809 & Salcedo & 50 & 200 \\
\hline
\end{tabular}


Table 1. Caddo populations through the Colonial era, cont.

\begin{tabular}{llll}
\hline Year & Source & Warriors* & Population \\
\hline 1828 & Berlandier & 50 & 200
\end{tabular}

\section{Nadaco}

\section{8}

1809

1828

1828

1856

1859

Ais
1716
1779
1805
$1818-20$
1820
1828
1828

\section{Kadohadacho}

1700
1709
1718
1719
1773
1798
1809
1805
$1818-20$
1820
1820
1825
1828
1829
1834
1836
1838
1838
1849
1851
1851
1854
1856
1857
1859

Davenport

Salcedo

Terán/Sanchez

Berlandier

Neighbors

Neighbors

French traders

De Mezieres

Sibley

Cincinnati Gazette

Padilla

Muckleroy/Terán

Berlandier

Bienville
La Harpe
Bienville
La Harpe
De Mezieres
Davenport
Salcedo
Sibley
Cincinnati Gazette
Miller
Padilla
Schoolcraft
Berlandier
Porter
Almonte
Morfit
Riley
Office of Indian Affairs
Neighbors
Stem
Upshaw
Hill
Neighbors
Neighbors
Neighbors

$\begin{array}{ll}100 & 400 \\ 100 & 400 \\ 29 & 116 \\ 30 & 150 \\ 38 & 190 \\ & 235\end{array}$

320

$20 \quad 80$

25

50

300

640

300

$\begin{array}{ll}500-600 & 2000-2400 \\ & 2500 \\ 200 & 800 \\ & 400 \\ 160 & 640 \\ 200 & 800 \\ 200 & 800 \\ 100 & 400 \\ 120 & 500-600 \\ 300 & 1200 \\ & 2000 \\ & 450 \\ 300 & 1200 \\ & 450 \\ & 500 \\ 250 & 1000 \\ 120-130 & 480-520 \\ 156+ & \\ 280 & 1400 \# \# \\ & 161++ \\ & 167+++ \\ & 500^{\wedge} \\ 35 & 175 \\ & 235 \\ & 244\end{array}$


Table 1. Caddo populations through the Colonial era, cont.

\begin{tabular}{llll}
\hline Year & Source & Warriors* & Population \\
\hline Natchitoches & Bienville & 450 & \\
1700 & Bienville & 80 & 1800 \\
1718 & La Harpe & & 320 \\
1719 & Sibley & 12 & 200 \\
1805 & Gray & 10 & 48 \\
1825 & Schoolcraft & & 40 \\
1825 & & & 61 \\
& & 3 & \\
Yatasi & De Mezieres & $40^{* * *}$ & 12 \\
1773 & Davenport & 8 & 160 \\
1798 & Sibley & 30 & 32 \\
1805 & Salcedo & 12 & 48 \\
1809 & Gray & & \\
1825 & equat to four & & \\
\end{tabular}

*one warrior is assumed to equate to four members of a family, but it is likely that this underestimates population sizes; some sources estimated five members to a family or five people per warrior.

**Nacogdoche and Ais groups; ***Yatasi and Adaes groups

+Shreveport Kadohadacho; ++Texas Kadohadacho only; +++Oklahoma Kadohadacho only; ^ Kadohadacho, Hainai, and Nadaco; \#Hasinai and Nacogdoche; \#\# Kadohadacho, Hainai, and Nadaco

With the permanent Anglo-American settlement of the region in waves of immigration after about 1815, it was the Caddos' misfortune to have been living on choice and fertile farmlands desired by the Anglo-Americans. In a few short years, they were dispossessed of their traditional homelands by the U.S. and Texas governments, their lands and goods swindled from them by U.S. Federal Indian agents in the Caddo Treaty of 1835, and eventually they were forced in 1859 to relocate from the Brazos Reserve in Texas to the Wichita Agency in western Oklahoma (then Indian Territory) (see Figure 14).

Shortly thereafter, the Caddo peoples were caught up in the Union and Confederate struggle for the Indian Territory during the Civil War, and with little trust for either the rebel or federal governments, the Caddo tribe abandoned their lands in Indian Territory for lands in Kansas, some fled as far as Colorado, but others, such as Caddo George Washington, a Major in the Confederate army, stayed and witnessed the 1862 destruction of Fort Cobb and the agency buildings. Caddo warriors that remained near Anadarko (along with an amalgamation of warriors from several other tribes) would also attack and almost exterminate the Tonkawa on October 24, 1862.

To date, there is a virtual absence of archaeological data from these Caddo Indian settlements, or on the 1860s and later Caddo settlements in western Oklahoma and Kansas. This is one of the great challenges in the years ahead: it remains to archaeologists to actually identify these Caddo settlements, which should contain significant and unique information on Caddo lifeways during a period of heightened acculturation and material culture changes.

Archaeology is a poor attendant to this period of Caddo strife and turmoil. It may be that Kadohadacho sites such as Timber Hill are not the prototype for this period; we simply do not know. It may also be the case that archaeologists have been reluctant to search for sites of this period, focusing instead on the many prehistoric Caddo sites with impressive mounds and burial grounds. Regardless, from 1835 to the present the U.S. government has done little to acknowledge the Caddo presence in East Texas and surrounding areas. For the most part, disregard has followed displacement. As archaeologists, it is surely important to make sure we are not complicit in this denying of Caddo cultural identity and their abiding connection to 
traditional homelands. Working to locate archaeological sites that date to this period is one course of action archaeologists can take towards re-affirming that the Caddo as a living people have an identity in East Texas.

The study of late eighteenth to mid-nineteenth century archaeology of the Caddo does not currently contribute as much as it could to a broader understanding of culture contact during frontier market economy times, despite a fairly rich archival record, at least in some respects. As stated above, the archaeology for this period is well nigh invisible. Archaeologists have played a haphazard role in Texas with respect to the acknowledgement and regard for the Caddo presence here and their connections to the history of Texas, and that is evident in the current state of archaeological knowledge about the Caddo in historic times.

The Caddo did not stand a chance of living in peace in Texas when the United States and Texas began land expropriations of the rich farmlands and woodlands that were the lands where the Caddo's homes stood. This was disastrous to the Caddo, and led to their eventual harried and forced removal from their homelands. Within a generation of settling land boundaries with the United States in 1835, and after attempting to cling to lands within the new Republic of Texas, the Caddo were gone from all of Texas. It is our hope that Caddo archaeologists will take on the role of working to renew support for the past and present native history, and the enduring connection to traditional homelands, of the Caddo.

\section{RECOMMENDED READINGS}

Barr, Juliana

2007 Peace Came in the Form of a Woman: Indians and Spaniards in the Texas Borderlands. University of North Carolina Press, Chapel Hill.

Bolton, Herbert E.

1987 The Hasinais: Southern Caddoans as seen by the Earliest Europeans. University of Oklahoma Press, Norman.

Bolton, Herbert E. (editor)

1914 Athanase de Mezieres and the Louisiana-Texas Frontier, 1768-1780. 2 Vols. Clark Publishing, Cleveland.

Carter, Cecile E.

1995 Caddo Indians: Where We Come From. University of Oklahoma Press, Norman.

Chafe, Wallace

2005 Caddo. In The Native Languages of the Southeastern United States, edited by H. K. Hardy and J. Scancarelli, pp. 323-350. University of Nebraska Press, Lincoln.

Dorsey, George A.

1905 Traditions of the Caddo. Publication No. 41. Carnegie Institution of Washington, Washington, D.C. Reprinted 1997 by University of Nebraska Press, Lincoln.

Flores, Dan L. (editor)

1984 Jefferson \& Southwestern Exploration: The Freeman \& Custis Accounts of the Red River Expedition of 1806. University of Oklahoma Press, Norman.

Foster, William C. (editor)

1998 The La Salle Expedition to Texas: The Journal of Henri Joutel, 1684-1687. Texas State Historical Association, Austin.

Girard, J. S., T. K. Perttula, and M. B. Trubitt

2014 Caddo Connections: Cultural Interactions Within and Beyond the Caddo World. Rowan \& Littlefield, Lanham, Maryland. 
Goldberg, M. A.

2009 Negotiating Nacogdoches: Hasinai Caddo-Spanish Relations, Trade Space, and the Formation of the Texas-Louisiana Border, 1779-1819. American Indian Culture and Research Journal 33.

Gregory, Hiram F.

1973 Eighteenth Century Caddoan Archaeology: A Study in Models and Interpretation. Ph.D. dissertation, Department of Anthropology, Southern Methodist University, Dallas.

Gregory, Hiram F. (editor)

1986 The Southern Caddo: An Anthology. Garland Publishing, New York.

Griffith, William J.

1954 The Hasinai Indians of East Texas as Seen by Europeans, 1687-1772. Philological and Documentary Studies, Vol. 2, No. 3. Middle American Research Institute, Tulane University, New Orleans.

John, Elizabeth A. H.

1975 Storms Brewed in Other Men's Worlds: The Confrontation of Indians, Spanish, and French in the Southwest, 1540-1795. Texas A\&M University Press, College Station.

McCollough, M.

2004 Three Nations, One Place: A Comparative Ethnohistory of Social Change Among the Comanches and Hasinais During Spain's Colonial Era. Routledge, New York and London.

Miller, Jay

1996 Changing Moons: A History of Caddo Religion. Plains Anthropologist 41(157):243-259.

Neighbours, Kenneth E.

1973 Indian Exodus: Texas Indian Affairs, 1835-1859. Nortex Offser Publications, Quannah.

Newkumet, Vynola B. and Howard L. Meredith

1988 Hasinai: A Traditional History of the Caddo Confederacy. Texas A\&M University Press, College Station.

Parsons, Elsie C.

1941 Notes on the Caddo. Memoir 57. American Anthropological Association, Washington, D.C.

Parsons, Mark L., James E. Bruseth, Jacque Bagur, S. Eileen Goldborer, and Claude McCrocklin

2002 Finding Sha'chahdinnih (Timber Hill): The Last Village of the Kadohadacho in the Caddo Homeland. Archeological Reports Series No. 3. Texas Historical Commission, Austin.

Perttula, Timothy K.

2014 Archaeological Studies of the Hatchel Site (41BW3) on the Red River in Bowie County, Texas. Special Publication No. 23. Friends of Northeast Texas Archaeology, Austin and Pittsburg.

Rogers, J. Daniel and George Sabo III

2004 The Caddos. In Handbook of North American Indians, Volume 14, Southeast, edited by Raymond D. Fogelson, pp. 616-631. Smithsonian Institution, Washington, D.C.

Sabo, George, III

2012 The Teran Map and Caddo Cosmology. In The Archaeology of the Caddo, edited by Timothy K. Perttula and Chester P. Walker, pp. 431-447. University of Nebraska Press, Lincoln.

Smith, F. Todd

1995 The Caddo Indians: Tribes at the Convergence of Empires, 1542-1854. Texas A\&M University Press, College Station.

1996 The Caddos, the Wichitas and the United States, 1846-1901. Texas A\&M University Press, College Station. 
2005 From Dominance to Disappearance: The Indians of Texas and the Near Southwest, 1786-1859. University of Nebraska Press, Lincoln.

Swanton, John R.

1942 Source Material on the History and Ethnology of the Caddo Indians. Bulletin 132. Bureau of American Ethnology, Smithsonian Institution, Washington, D.C.

Tiller, James

2013 Before the Line. Vol. III, Caddo Indians: The Final Years. The START Group, Huntsville, Texas.

\section{REFERENCES CITED}

Carter, Cecile E.

1995 Caddo Indians: Where We Come From. University of Oklahoma Press, Norman.

Flores, D. L. (editor)

1984 Jefferson and Southwestern Exploration: The Freeman and Custis Accounts of the Red River Expedition of 1806. University of Oklahoma Press, Norman.

Parsons, M. L., J. E. Bruseth, J. Bagur, S. E. Goldborer, and C. McCrocklin

2002 Finding Sha'chahdinnih (Timber Hill): The Last Village of the Kadohadacho in the Caddo Homeland. Archeological Reports Series No. 3. Texas Historical Commission, Austin.

Robertson, J. A. (translator and editor)

1933 True Relation of the Hardships Suffered by Governor Fernando de Soto and Certain Portuguese Gentlemen during the Discovery of the Province of Florida now Newly Set Forth by a Gentleman of Elvas. Publications No. 11. Florida Historical Society, De Land.

Swanton, John R.

1942 Source Material on the History and Ethnology of the Caddo Indians. Bulletin 132. Bureau of American Ethnology, Smithsonian Institution, Washington, D.C. 